\title{
What is the relationship, if any, between the teacher -perceived school climate and the state accreditation status of elementary schools in West Virginia?
}

\author{
Elaine DellaMea Gayton \\ West Virginia University
}

Follow this and additional works at: https://researchrepository.wvu.edu/etd

\section{Recommended Citation}

Gayton, Elaine DellaMea, "What is the relationship, if any, between the teacher -perceived school climate and the state accreditation status of elementary schools in West Virginia?" (1999). Graduate Theses, Dissertations, and Problem Reports. 3164.

https://researchrepository.wvu.edu/etd/3164

This Dissertation is protected by copyright and/or related rights. It has been brought to you by the The Research Repository @ WVU with permission from the rights-holder(s). You are free to use this Dissertation in any way that is permitted by the copyright and related rights legislation that applies to your use. For other uses you must obtain permission from the rights-holder(s) directly, unless additional rights are indicated by a Creative Commons license in the record and/ or on the work itself. This Dissertation has been accepted for inclusion in WVU Graduate Theses, Dissertations, and Problem Reports collection by an authorized administrator of The Research Repository @ WVU.

For more information, please contact researchrepository@mail.wvu.edu. 
What is the relationship, if any, between the teacher-perceived school climate and the state accreditation status of elementary schools in West Virginia?

Elaine DellaMea Gayton

Dissertation submitted to the

College of Human Resources and Education

at

West Virginia University

In partial fulfillment of the requirements for the degree of

Paul A. Leary, Ed. D., Doctoral Committee Chair

Jo Blackwood, Ed. D.

Michael Cunningham, Ed. D.

C. Kenneth Murray, Ed. D.

Jack E. Yeager, Ed. D.

Department of Educational Leadership Studies

Morgantown, West Virginia

1999

Keywords: School Climate, School Size, SES, Accreditation, CFK

Copyright 1999 Elaine DellaMea Gayton 


\section{ABSTRACT \\ What is the relationship, if any, between the teacher-perceived school climate and the state accreditation status of elementary schools in West Virginia?}

\section{Elaine DellaMea Gayton}

The purpose of the study was to determine if a significant relationship exists between teacher-perceived school climate and state accreditation of elementary schools in West Virginia. Teacher-perceived school climate was measured by the CFK School Climate Profile.

The sample consisted of 100 schools. Included were 53 randomly-selected elementary schools which earned full accreditation and 47 elementary schools which lacked full accreditation in 1998 due to results on the Stanford Achievement Test. The response rate was 65\%. Statistical analysis of data occurred through t-tests and stepwise multiple regression with an alpha level of .05 applied.

Findings: The percentage of students eligible to receive free or reduced lunch ranged from $11 \%$ to $99 \%$ in respondent schools and was significantly greater in schools which lacked full accreditation (79\%) compared to schools which earned full accreditation (54\%). Student enrollment in respondent schools ranged from 68 to 950 students and was significantly greater (358) in schools which earned full accreditation compared to schools which lacked full accreditation (215).

Mean climate scores were significantly higher in schools which earned full accreditation than in schools which lacked full accreditation. In lower SES schools, high morale was identified as a predictor of school accreditation. In smaller schools, cohesiveness and SES were predictors of school accreditation. In larger schools, only SES was a predictor of school accreditation.

Conclusions: 1. High morale is related to student achievement. Therefore, high morale is related to state accreditation of elementary schools in West Virginia. Two possible phenomena exist to explain this finding. a) High morale may be lower in schools which lack full accreditation due to the lack of accreditation. b) Lower morale may lead to a school's lack of full accreditation.

2. Cohesiveness was found to be lower in small schools which lacked full accreditation. A sense of cohesiveness may cultivate working together toward common goals. Working together may lead to higher student achievement and possibly full accreditation.

3. Findings indicate SES is related to student achievement measured by standardized tests. It is likely that in low SES schools, the greatest number of students will score below the 50th percentile in a normal distribution, and as a result may lack full accreditation status.

4. In higher SES schools students may be members of families in which parents earn better wages and perhaps have more education. Parents with more education may understand the educational process better and may place more emphasis upon education. Students from higher SES backgrounds may have broader life experiences which may enable them to relate better to items on standardized achievement tests. 


\section{ACKNOWLEDGMENTS}

Completing the doctoral program has been a personal and professional endeavor that would not have been possible without the support and encouragement from many admirable individuals. My sincerest appreciation is extended:

To my doctoral committee: Dr. Paul Leary, chairperson; Dr. Jo Blackwood, Dr. Michael Cunningham, Dr. Ken Murray, and Dr. Jack Yeager. Their encouragement, support, and assistance enabled me to grow both personally and professionally throughout the process of working toward the Ed. D. degree. Committee members helped to make the process enjoyable as well as educational, and I greatly appreciate their efforts.

To Dr. Teresa Hardman, Dr. Kathleen Warner, and Pam Mullins for providing assistance in their special areas of expertise.

To Debbie Wood for always being cheerful and eager to assist with any program needs or questions I may have had throughout the entire process.

To my aunts, Mabel and Rose DellaMea, for continuously reinforcing the notion throughout my life that one has to work hard for everything and that nothing is free. This belief enabled me to persevere in my goal of completing the doctoral program.

To my sisters, Carla DellaMea-Luketic and Cecelia DellaMea, for providing encouragement and support throughout the entire process.

To my parents, Carl and Lena DellaMea, who I hope, see that I have come a long way since my "eighth grade science questions," and who have provided continuous support and encouragement to always do my best.

Finally, I dedicate this dissertation to my husband, Michael Gayton, who displayed 
wonderful patience in enduring the great amount of time I spent reaching this goal and who provided continuous encouragement and support. 


\section{TABLE OF CONTENTS}

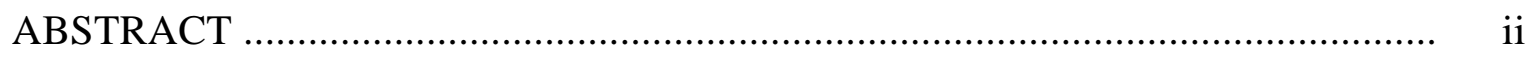

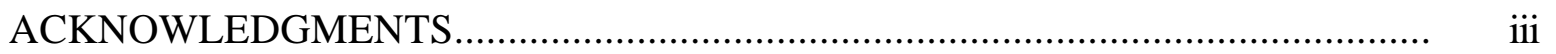

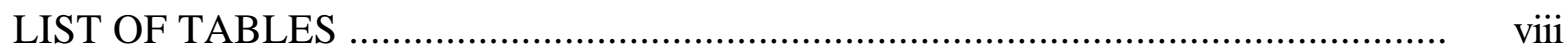

\section{CHAPTER 1}

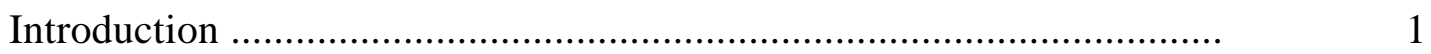

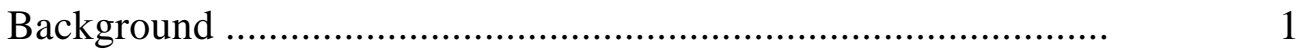

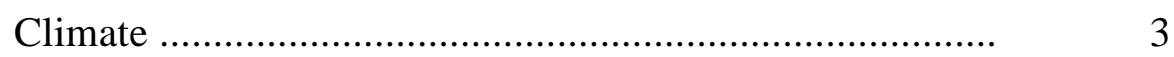

Measuring Climate ……................................................

Socioeconomic Status and School Size ………………........ 8

Accreditation Status in West Virginia Public Schools ........... 10

Climate and Accreditation .................................................. 13

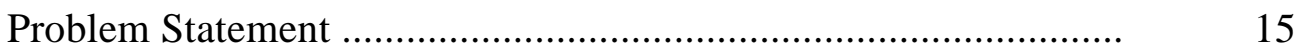

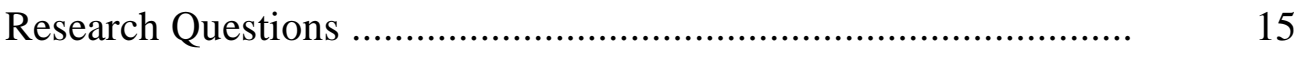

Operational Definitions ............................................................... 16

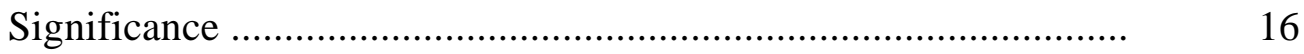

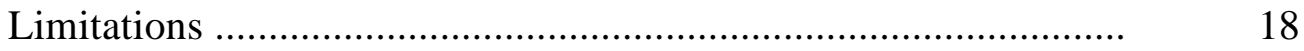

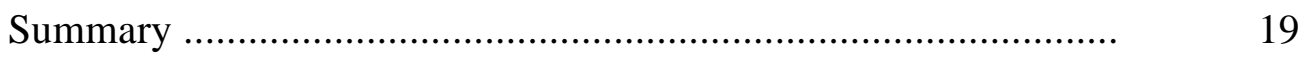

\section{CHAPTER TWO}

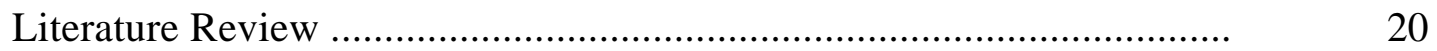

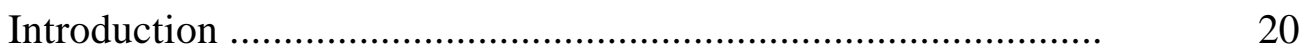

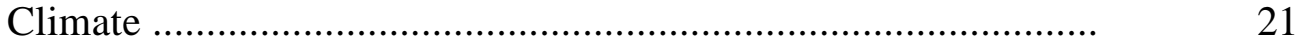


Measuring Climate ........................................................ 25

Socioeconomic Status ......................................................... 29

School Size ..................................................................... 31

School Accreditation Status .................................................. 35

Climate and School Accreditation ........................................... 38

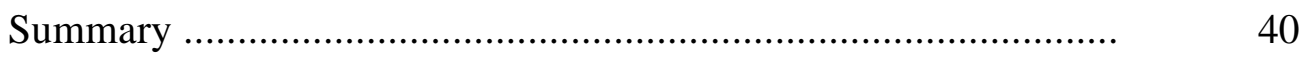

CHAPTER THREE

Research Procedures ................................................................ 42

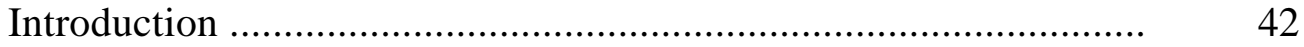

Design .......................................................................... 43

Population and Sample ...................................................... 43

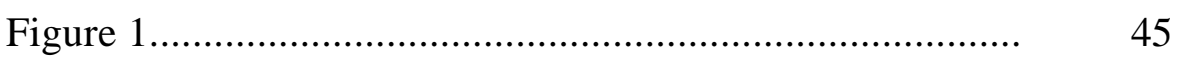

Instrumentation ................................................................ 46

Methods ......................................................................... 47

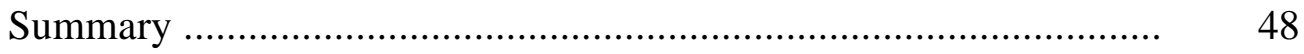

\section{CHAPTER FOUR}

Presentation and Analysis of Data ..................................................... 49

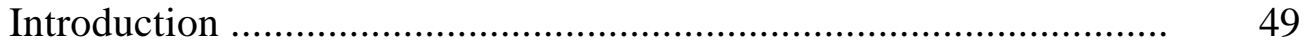

Descriptive Data ............................................................. 50

Statistical Analysis of Data ......................................................... 52

Major Findings ….......................................................... 55

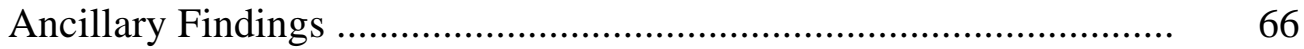


Summary

CHAPTER FIVE

Summary, Conclusions, Recommendations ………………………................. 72

Summary of Purpose and Procedure ……………………………...... $\quad 72$

Summary of Descriptive Data …………………………………..... 73

Summary of Findings …………….............................................. 73

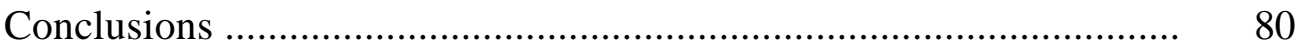

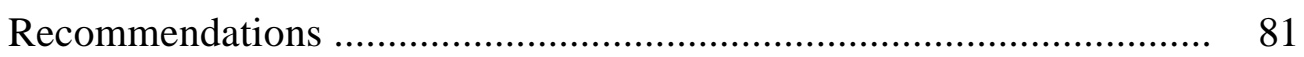

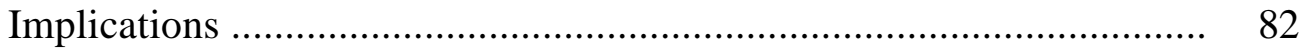

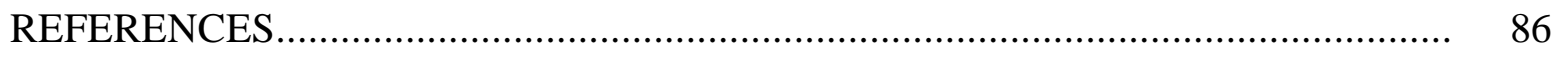

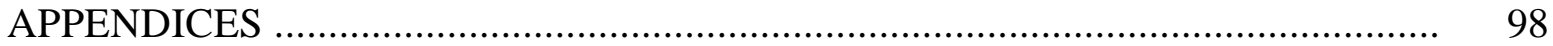




\section{List of Tables}

\section{Table}

Page

Table 1 Accreditation Status, Response Rate, SES, and Size

52

Table $2 \quad$ Group Statistics

Table 3 Independent Samples T-test - Difference Between Group Means

Table 4 Schools with $>$ or $=$ to $66 \%$ Free and Reduced Lunch (Low SES Schools)

Group Statistics

Table 5 Independent Samples T-test for Equality of Means Schools with $>$ or $=66 \%$

Free and Reduced Lunch (Low SES)

Table $6 \quad$ Stepwise Multiple Regression Low SES Schools

Table 7 Schools with $<66 \%$ Free and Reduced Lunch - Group Statistics

60

Table 8 Schools with Enrollment $>$ or $=290$ (Large Schools) - Group Statistics 
Table 9 Independent Samples T-test for Equality of Means Schools with $>$ or $=290$ Students

Table $10 \quad$ Stepwise Multiple Regression Schools with $>290$ Students (Large Schools)

Table 13 Stepwise Multiple Regression Schools with < 290 Students (Small Schools)

Table 15 Independent Samples T-test for Equality of Means Schools with $<290$ Students and SES > or $=66 \%$ (Small Schools with Low SES) 
Table 17 Ancillary Findings Independent Samples T-test for Equality of Means

Schools Which Lacked Full Status in 1997 and 1998 and

Schools Which Lacked Full Status in 1998 Only

Table 18 Stepwise Multiple Regression Schools Which Lacked Full Status in 1997 and 1998 and Schools Which Lacked Full Status in 1998 Only 


\section{Chapter One}

\section{INTRODUCTION}

"The ultimate goal of any principal is to have a school that works" (DeMoulin, 1994, p. 31). Leader behaviors and the impact of the behaviors upon school effectiveness have been the subject of studies dating back to the 1960s (Bailey, 1988). An effective school is one in which high levels of student achievement are sustained over time, and students from lower socioeconomic backgrounds perform at levels comparable to those students from backgrounds of higher socioeconomic status (Chrisspeels, 1990). Student achievement (Marockie, 1997; 1998), and therefore school effectiveness (Chrispeels, 1990), project the state accreditation status of elementary schools in West Virginia (WV, Policy 2320). Recent inquiries relating to school effectiveness indicate that leadership behaviors and school climate are factors which may influence the effectiveness of a school (Bailey, 1988).

\section{BACKGROUND}

Coleman (1966) concluded that the school could make no difference in student achievement. Results of the Coleman study indicated the independent, input variables (physical facility, resources, services, extracurricular activities, and teacher/principal characteristics) had no bearing upon the output variable, student achievement. The only variable that did appear to impact student achievement according to Coleman was the socioeconomic status of the student. Coleman concluded that student achievement was a function of family background.

Much debate emerged as a result of Coleman's report (Bailey, 1988). Weber (1971) disputed Coleman's findings and found that schools which placed an emphasis upon reading instruction, frequent and careful monitoring of student progress, a safe and orderly climate, and 
specific leadership behaviors demonstrated by the principal did lead to higher student achievement.

In a 1974 analysis sponsored by the state of New York, researchers concluded that student achievement was associated with factors under the school's control, such as the school climate and behaviors demonstrated by the school leader. The principal in the more effective of two New York schools devised a plan for reading remediation. The principal also possessed management and instructional skills, observed students and teachers frequently, was involved in district plans for school improvement, established educational practices, and developed a stable school environment (State of New York, 1974).

Continuing the aforementioned trend, Madden (1976) identified five components that were indicative of an effective school. Identified components were: (a) Teachers received support from the principal; (b) A positive climate existed; (c) The principal influenced the instructional process; (d) Student progress was highly monitored; and 5) Emphasis was placed upon achievement. According to Edmonds and Frederiksen (1978), engagement and promotion of specific behaviors were demonstrated by the school leader in effective schools. Demonstrated behaviors in effective schools included cultivating an orderly climate, monitoring and assessing student progress systematically, emphasizing instruction, setting clear goals and objectives, developing and communicating a plan for remediation, and providing strong leadership and management skills. In an additional inquiry by Edmond (1979), administrative leadership style and climate appeared together as factors associated with school effectiveness. Edmond (1979) identified additional factors that were related to school effectiveness. Factors cited were emphasis upon basic skills, high teacher expectations, and continuous monitoring and assessment of basic skills. 
Zakariya (1984) identified variables similar to those variables recognized by Edmond (1979).

Wood (1998) reported that outstanding leadership was the catalyst for a school's educational excellence. Wood identified eight effective school correlates. Correlates identified were: (a) emphasis upon student acquisition of skills; (b) appropriate monitoring of skills, (c) practiceoriented staff development, (d) parent involvement, (e) effective instructional arrangements, (f) high expectations and requirements, (g) outstanding leadership, and (h) a productive school climate. Principals of schools in Alabama, rated effective by the districts' superintendents, were found to exhibit behaviors indicative of a more positive school climate than principals in schools rated less effective by district superintendents (Almond, 1993).

\section{$\underline{\text { Climate }}$}

While researchers do not have a common definition for climate, Drake (1997) referred to climate as the tone of the building, the feelings one has while inside the building, and the order of things. While perceptions may vary about what represents climate, it is accepted by researchers that it is a shared pattern of characteristics (Bailey, 1988). Kelley (1980) described the climate of a school as that which is formed by the "... norms, beliefs, and attitudes reflected in conditions, events, and practices of the specific environment." Climate is said to refer to the conditions that abound in a social setting and endure over time, and which influence the behavior of group members in the specific setting. Member behaviors distinguish one environment from another (Bailey, 1988).

Although the concept of school climate has been studied to a great extent and a lack of agreement upon the definition exists (Sackney, 1988), some may use the terms atmosphere, feelings, tone, setting, health, and culture when describing school climate. Halpin and Croft 
(1963) stated "personality is to the individual what climate is to the organization" (p. 1). Tagiuri (1968) defined climate as the total environmental quality which includes the dimensions of ecology (the physical and material components), milieu (the social dimension of people), and culture (the belief systems, values, cognitive structures, and meanings).

Hoy and Miskel (1987) defined climate as "the set of internal characteristics that distinguishes one school from another and influences the behavior of people" (p. 225). Sackney (1988) considers school climate to be an enduring quality of the internal environment that is experienced by all members of the organization (students, teachers, administrators, and service personnel). The enduring quality of the internal environment influences the behavior of members and can be described in terms of the values, norms, and beliefs which promote a specific set of school attributes. Attributes include institutional patterns and behavior that enhance or impede student achievement.

Even if agreement upon the definition and conceptualization of school climate did occur, several issues would still require deliberation (Sackney, 1988). Two such issues, which relate to this inquiry, are: (a) How does one objectively describe (i.e., assess, measure) the climate in a given school? What are the variables that create various climates, and how can they be measured and described? (b) Is there a relationship between the climate of the school and the effectiveness of the school, which consequently, results in school accreditation?

\section{Measuring Climate}

Numerous instruments have been used to measure school climate. Instruments based upon Murray's (1938) theoretical background are the Classroom Environmental Scale (CES), The

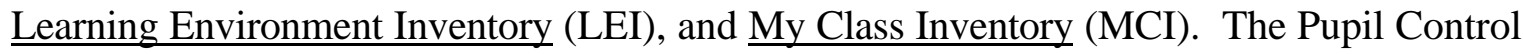


Ideology (PCI) was developed in 1967 by Willover, Eidell, and Hoy. The purpose of the PCI was to measure teacher and principal orientation to pupil control. The Profile of Organizational Characteristics (POC) was developed by Likert (1961). Likert developed the POC as an indicator of superordinate-subordinate relationships in organizations. Additional instruments developed for the purpose of measuring school climate were the High School Characteristic Index (HSCI), The Elementary School Environment Survey (ESES), and My School Inventory (MSI), which was adapted from the MCI. The Quality of School Life (QSL), developed by Epstein and McPartland (1976), is based upon the belief that school life is affected by the formal and informal aspects of schooling by social experiences, task-related experiences, and relationships between peers and authority figures (Sackney, 1988).

The Organizational Climate Description Questionnaire (OCDQ) was developed by Halpin and Croft at Ohio State University in 1962. According to Sackney (1988), the OCDQ is probably the most widely-used, and over-used, instrument in determining school climate. The OCDQ was utilized in recent studies by Al-Gasim, 1991; Edwards, 1994; Hansen, 1992; Jackson, 1997; Villani, 1996; and Williams, 1980. Halpin and Croft (1962) defined climate as a combination of two dimensions of social behaviors: principal-teacher interactions and teacher-teacher interactions. The first component, principal's style of interaction with teachers, includes three elements. Elements are (a) support and genuine concern for the teacher; (b) direction and orientation toward task with little concern for teacher; and $\odot$ restriction that hinders the teacher rather than providing support for him or her.

The second component of school climate, teachers' behaviors and interactions with one another, includes the following elements: (a) collegial behavior and supportive professional 
relationships; (b) intimate behavior and friendship outside the school environment; and

(C) disengaged behavior or alienation among peers (Bailey, 1988).

Halpin and Croft (1962) stated that school climate is analogous to the school's personality and can be defined by the perception members of the organization have of the association.

Degrees of climate existing within organizations range from closed (negative) to open (positive). A closed climate is characterized as disengagement of group members, hindrance by the group leader, aloofness by the group leader, and emphasis only upon production with low degrees of the leader behavior, consideration.

An open climate is characterized by high degrees of trust, consideration, and esprit de corps (Halpin and Croft, 1962; Lowe, 1995). Like the OCDQ, the Charles F. Kettering Ltd. School Climate Profile measures school climate based upon the perception of members in the organization.

A study of school climate sponsored by the Charles F. Kettering Foundation (Fox, 1973) cataloged the goals of school climate as productivity and satisfaction. The eight climate factors within these categories include respect, trust, high morale, opportunity for input, continuous academic and social growth, cohesiveness, school renewal, and caring. As a result of the study, the Charles F. Kettering, Ltd. School Climate Profile (CFK Ltd. School Climate Profile) was developed. Climate refers to a concern for both productivity and satisfaction as well as the relationship which exists between the two dimensions (Bailey, 1988). The eight characteristics of the managerial systems method of defining climate (Likert, 1961) laid the groundwork for the climate factors identified by the CFK Ltd. School Climate Profile. Factors included leadership processes; motivational forces; communication processes; interaction-influence processes; 
decision-making processes; goal setting; control processes, and performance goals and training (Likert, 1961).

Like the OCDQ, the CFK Ltd. School Climate Profile appears quite frequently in recent literature. (Bailey, 1988; Dicksen, 1991; Salas, 1992; Sellers, 1984; and Steuven, 1985). Both the OCDQ and CFK, Ltd. School Climate Profile measure relationship oriented and production oriented climate components. An open climate is considered positive (Halpin and Croft, 1962) with high levels of trust, high morale, cohesiveness, and caring, all of which are climate factors measured by the CFK, Ltd. School Climate Profile (Bailey, 1988). A closed or negative climate is characterized by disengagement (Halpin and Croft, 1962), which corresponds to a lack of opportunity for input and continuous academic and social growth. Opportunity for input and continuous academic and social growth are climate factors measured by the CFK, Ltd. School Climate Profile (Bailey, 1988). The CFK Ltd. School Climate Profile was used in this study to measure teacher-perception of school climate in West Virginia elementary schools.

A plethora of research indicates a relationship between school climate and school effectiveness (Almond, 1993; Edmond, 1978; Gentile, 1997; Jackson, 1997; Madden, 1976; Rasmussen, 1995; State of New York, 1974; Stockton, 1997; Vardett, 1998; Woods, 1998). School leadership plays a vital role in shaping the climate of the building (Al-Gasim, 1991; Almond, 1993; Bailey, 1988; Dickson, 1991; Edwards, 1994; Jackson, 1997; Johnson, 1991; Rasmussen, 1995; Sellers, 1984; Stockton, 1997; Stueven, 1985; Villani, 1996; Williams, 1980), with school effectiveness defined as high student achievement sustained over time in all socioeconomic classes (Chrispeels, 1990). Staff morale and dedication render a vital role in the achievement level of the school's mission and the student levels of achievement (Gentile, 1997). 
Vardett (1998) identified school climate as an indicator of student achievement in North Carolina Elementary Schools. Utilizing the Organizational Health Inventory for Elementary Schools (OHI-E), Watts (1997) concluded that a healthy school climate, with special emphasis on the presence of principal leadership high both in consideration and task initiative, and an academic climate with high expectations will increase student achievement. In addition to school climate, school size and the socioeconomic status (SES) of students have been identified as having an impact upon student achievement, and therefore upon the accreditation status of schools. Watts, whose inquiry was limited to elementary schools in a southern region of West Virginia, recommended additional study because significance between variables was marginal. Watts (1996) did ascertain that a strong relationship between the socioeconomic status (SES) of students and student achievement existed within the sample analyzed.

Jones (1996) deduced that both school climate and SES were predictors of student achievement. The relationship between the SES of students and achievement as well as between school climate and student achievement have been the probe of additional investigations (Howley, 1996; Finklea, 1997; McKee, 1996; Peach, 1996; Summers, 1992; Surya, 1994; Schwaninger, 1997).

\section{$\underline{\text { Socioeconomic Status of Students and School Size }}$}

McDonald-Risik (1997) determined that students scored higher on the Texas Assessment of Academic Skills (TAAS) when school climate was perceived as positive. In addition, McDonaldRisik (1997) concluded that no significant relationship existed between student achievement and the following factors: diversity in school size, socioeconomic status of students, ethnicity, and mobility rate of students. Like McDonald-Risik, Clarke's (1997) findings indicated no 
significant relationship between student achievement, defined as grade point average, and SES.

The results of many inquiries do indicate a significant relationship between SES and student achievement (Howley, 1996; Finklea, 1997; McKee, 1996; Peach, 1996; Summers, 1992; Surya, 1994; Schwaninger, 1997). In a South Carolina analysis, Finklea (1997) determined that a negative correlation existed between the socioeconomic status (SES) of students and school effectiveness measured by the Metropolitan Achievement Test, Seventh Edition (MAT-7). Surya (1994) resolved that family background had a strong influence on student achievement in Pennsylvania schools. Student achievement appeared lower in groups of low SES schools as compared to student achievement in groups of higher SES schools (Surya, 1994).

Howley (1996) concluded that both the SES of students and school size influenced student achievement in West Virginia public schools. Findings, according to Howley, indicated that small schools benefit impoverished children and larger schools benefit affluent children.

McKee (1996) found that African-American students scored higher in reading and math on standardized tests when attending larger urban and suburban schools than African-American students attending smaller schools. McKee's conclusions (1996) also indicated that students who paid for their lunch scored higher on the same tests than those students receiving free or reduced lunch. Conclusions reached by Arnold (1996) lead one to believe that students attending small rural schools achieve at lower levels than those in other types of schools.

Stevenson and Pellicer (1998) synthesized findings by numerous researchers (Stemnock, 1974; Howley, 1989; McGuffey 1991; Lamdin, 1995; Stevenson \& Pellicer, 1996) to conclude that while there are clear arguments for both large and small schools, when control was provided for SES larger schools were identified as demonstrating better academic performance by students 
than smaller schools according to recognition by state and national organizations. Stevenson \& Pellicer also reported that there is no optimal size for schools and that well-trained and dedicated teachers, visionary leaders, and concerned and involved parents and communities that value quality education are the factors that make a positive difference.

Peach (1996) discovered that a consistent difference in mean reading and math scores on the Missouri Mastery and Achievement Test (MMAT) existed between students of low SES and students of non-low SES. Students of non-low SES earned a mean score 20 or more points higher than students of low SES. Schwaninger (1997) also concluded that student SES had an impact upon academic achievement with students of low SES demonstrating lower achievement on the Iowa Tests of Basic Skills.

The current investigation attempted to determine if school size and the socioeconomic status of students, in conjunction with the independent variable school climate, are predictors of accreditation status in West Virginia elementary schools .

\section{$\underline{\text { Accreditation Status in West Virginia Public Schools }}$}

Student achievement (Marockie, 1997; 1998) is the primary criteria used to grant state accreditation status to elementary schools in West Virginia (WV Policy 2320). The Stanford Achievement Test, Ninth Edition, (SAT-9) measures student achievement in West Virginia schools. School effectiveness, as judged by the West Virginia Performance Based Accreditation System, SAT-9 test results, student attendance, and school drop-out rate, determines school accreditation in West Virginia.

Instruction must be based at a minimum on the West Virginia Instructional Goals and Objectives (West Virginia Board of Education Policy, 2520). Student acquisition of skills in 
grades three through 11, established by the West Virginia Instructional Goals and Objectives, is assessed every spring through student completion of the Stanford Achievement Test, Ninth Edition (SAT-9). Fite (1995), in a University of Missouri analysis, recommended that curriculum and instruction be driven by data of student achievement. Whether or not state education officials in West Virginia were familiar with Fite's conclusion is unknown. However, schools within West Virginia have implemented Fite's recommendation by basing instruction on outcomes of student test data which reflect the West Virginia Instructional Goals and Objectives (West Virginia Board of Education Policies, 2510, 2520).

Baseline SAT-9 scores were achieved through Spring 1997 testing. Schools in which fifty percent of the students enrolled in grades three through 11 did not score within the upper two quartiles, were placed on academic probation in accordance with state policy (Marockie, 1997).

All elementary schools which were reported to have received probationary status in the December 1997 (Marockie) accreditation report received the status having due to less than fifty percent of the students failing to score above the fiftieth percentile. Additional factors could lead to a school's lack of full accreditation status. Additional factors are as follows: (a) Beginning with spring 1999 testing, greater than fifteen percent of students in grades three through six must not score within the bottom quartile on the Stanford Achievement Test; (b) Student attendance must not fall below the state established rate; ( ) Student dropout rate must be below six percent; and (d) Schools must be in compliance with all standards set forth by the West Virginia Performance Based Accreditation System when assessed through an on-site review process.

As a result of Spring 1998 SAT-9 testing, 47 elementary schools were unable to achieve full accreditation status. Sixty-one of the elementary schools previously lacked full accreditation 
status in 1997 but earned full approval as a result of spring 1998 testing (Marockie, 1998). Thirty-one of the schools that received probationary approval in 1997 continued to lack full accreditation as a result of 1998 test results (Marockie, 1998). In December 1998, The West Virginia Performance Based Accreditation System (Marockie, 1998) reported 16 additional elementary schools that failed to receive full accreditation status due to test results. Six additional schools lacked full approval due to failure of the state on-site review process. Those six schools and the 61 schools which lacked full accreditation only in 1997 were omitted from the population and sample of this inquiry. The sample groups were unequal in size because six schools, which lacked full approval due to noncompliance discovered during the on-site review process, were removed from the sample. Fifty-three schools which earned full approval in both 1997 and 1998 were randomly selected before the six schools were removed.

The term probationary status was changed to temporary or conditional accreditation in December 1998 (West Virginia Department of Education, Policy 2320). This change occurred as a result of 1998, House Bill 4306 (West Virginia, §18-2E-5). Each school that received temporary accreditation status was given the opportunity to revise its Unified School Improvement Plan (USIP) in order to receive conditional approval. For each school which received conditional status, a designated amount of time was agreed upon when school performance standards would be in compliance with established state performance standards. That is, fifty percent of students in grades three through eleven must score within the upper two quartiles, and beginning in spring 1999, not greater than fifteen percent may score within the bottom quartile on the state-mandated achievement test (West Virginia Department of Education, Policy 2320). Schools who fail to meet the established performance standards may be rated as 
“seriously impaired" (West Virginia Department of Education, Policy 2320). If one school within a county school district in the state of West Virginia receives seriously impaired status, the district may receive non-approval by the West Virginia Performance Based Accreditation System (West Virginia Department of Education, Policy 2320).

Four hundred forty-three elementary schools were identified in the state of West Virginia (Marockie, 1998). Elementary schools are those school which serve students in pre-kindergarten or kindergarten through at least fourth garde, but no higher than sixth garde. Ninety-five elementary schools received probationary approval as a result of spring 1997 Stanford Achievement Test results, and 47 schools did likewise as a result of spring 1998 Stanford Achievement Test results (Marockie, 1997; 1998). Additional elementary schools with various grade level configurations received probationary status, but the schools did not meet the definition of elementary school as stated in this study.

\section{$\underline{\text { Climate and Accreditation }}$}

The second issue raised by Sackney (1988) which pertains to this inquiry is whether or not a relationship exists between school climate and student achievement. Student achievement is the basis for state accreditation of West Virginia public schools. Gentile (1997) concluded that school climate and teacher morale influenced student achievement in Pennsylvania middle schools. Students scored higher on the Pennsylvania Assessment Tests in reading and mathematics when school climate was more positive, and teachers displayed higher morale. Tom (1995), however, ascertained that no relationship existed between school climate and student achievement on selected public school campuses in Del-Rio, Texas. Tom defined student achievement as scores on the Norm-Referenced Assessment Program for Texas (NAPT). 
The results of numerous additional studies do indicate that the school climate has an impact upon the effectiveness of the school (Almond, 1993; Edmonds, 1978; Gentile, 1997; Jackson, 1997; Madden, 1976; Rasmussen, 1995; State of New York, 1974; Stockton, 1997; Woods, 1998). Schools with positive climates are said to exhibit people centered beliefs and values, systems, rules, regulations, procedures, and policies (Bailey, 1988; Howard, 1981). Schools with negative climates are said to be institution centered rather than people centered (Bailey, 1988; Howard, 1981).

Current literature clearly indicates that a relationship exists between leader behaviors and school climate (Al-Gasim, 1991; Almond, 1993; Bailey, 1988; Dickson, 1991; Edwards, 1994; Jackson, 1997; Johnson, 1991; Rasmussen, 1995; Sellers, 1984; Stockton, 1997; Stueven, 1985; Villani, 1996; Williams, 1980) and between school climate and student achievement (Almond, 1993; Edmonds, 1978; Finklea, 1997; Gentile, 1997; Jackson, 1997; Madden, 1976; Rasmussen, 1995; State of New York, 1974; Stockton, 1997; Woods, 1998; Zielke, 1989). Because it has been indicated that leader behaviors affect climate, and climate affects student achievement, one may therefore conclude that a relationship exists between leader behaviors and student achievement as well (Almond, 1993; Edmonds, 1979; Chrisspells, 1990; Finklea, 1997; McDonald-Risik, 1997; Rasmussen, 1995; State of New York, 1974; Weber, 1971; Woods, 1998;). School climate has been characterized as the single most important expression of educational leadership with the principal displaying the ability to build a climate that is supportive, challenging, and positive as everyone directs his or her attention toward school goals, student achievement, and personal relationships (Bailey, 1988; Kelley, 1980; Rutter, et al., 1979).

No paucity of research indicates there are specific task-oriented and relationship-oriented 
leader behaviors which impact school climate (Al-Gasim, 1991; Ausejo, 1983; Bailey, 1988;

Jackson, 1997; Johnson, 1991; Rasmussen, 1995; Sellers, 1984; Stockton, 1997; Villani, 1996;

Willaims, 1980;). In fact, every study of effective schools has determined that efficient

administrative leadership is essential in establishing and maintaining a climate conducive to academic learning and achievement (Bailey, 1988).

\section{PROBLEM STATEMENT}

Full state accreditation status awarded to schools based on student achievement test results has become a major emphasis in elementary schools state-wide. A large portion of instructional time is often devoted to practice of test-taking skills as well as to curriculum included in the West Virginia Instructional Goals and Objectives at all grade levels. Increased student achievement on the Stanford Test seems to have become the main mission of schools throughout the state of West Virginia. Students in some schools have historically scored lower on norm-referenced tests such as the Stanford Achievement Test and its predecessor, the Comprehensive Test of Basic Skills (CTBS). The purpose of this study is to determine if school climate, the socioeconomic status of students attending schools, and school size are related to the state accreditation status of elementary schools in West Virginia.

\section{RESEARCH QUESTIONS}

Data collected from this investigation was used to answer the following questions:

1. What is the relationship, if any, between the teacher-perceived school climate and the state accreditation status of elementary schools in West Virginia?

2. What is the relationship, if any, between the teacher-perceived school climate, in conjunction with the socioeconomic status of students, and the state accreditation status of 
elementary schools in West Virginia?

3. What is the relationship, if any, between the teacher-perceived school climate, in conjunction with school size, and the state accreditation status of elementary schools in West Virginia?

\section{OPERATIONAL DEFINITIONS}

1. Teacher-perceived school climate is defined as a teacher-respondent mean score on the forty-item CFK Ltd. School Climate Profile.

2. Accreditation status of elementary schools in West Virginia is defined as schools receiving full accreditation status or lacking full accreditation status based on student achievement determined through spring 1998, Stanford Achievement Test results. The term Probationary Accreditation status includes Temporary Accreditation status (TA), Conditional Accreditation status (CA), and Seriously Impaired (SI) status.

3. School size is defined as the number of students enrolled in the school according to the second month West Virginia Education Information Systems (WVEIS) report.

4. The socioeconomic status (SES) of schools is defined as the percentage of students who are eligible to receive United States Department of Agriculture (USDA) free or reduced lunch in the school, as reported by the West Virginia Department of Education, Office of Child Nutrition.

5. Elementary school is defined as a school serving students in grades pre-kindergarten or kindergarten through at least fourth grade, but no higher than sixth grade.

\section{SIGNIFICANCE}

Due to the high standards which lead to school accreditation within the state of West Virginia, this inquiry provides information to personnel in schools and school districts within the 
state. Findings from this inquiry may assist school personnel in understanding a need to improve school climate, and therefore may assist them in improving school accreditation status. Schools and school districts which receive full accreditation status are more likely to retain local control of education than schools or school districts which lack full accreditation status.

School climate has been identified as a variable which may be related to student achievement. Leadership behaviors have been identified as having a potential influence upon school climate.

Gulick (1937) identified administrative functions as planning, organizing, staffing, directing, coordinating, reporting, and budgeting. Because school climate, school size, and leader behaviors can be changed, the identification of characteristics associated with fully accredited schools could lead to an emphasis on administrative functions. Functions may be acted upon by principals in order to build a positive school climate or change specific leader behaviors. Principals may plan, budget, and organize professional development activities, coordinate instructional activities, and coordinate staffing related to outcomes of this inquiry. Staff developers and directors may organize, plan, coordinate, and budget professional development for school administrators and teachers using information derived through the current study. Superintendents may utilize the information with administrative staffing, redistricting or consolidation plans, and budgeting purposes.

Professors in colleges and universities may use the information from this report in educational administration and leadership programs in curriculum planning, in coordinating pre-service and inservice activities for potential and current administrators, and in coordinating activities with local school districts. Personnel with the West Virginia Department of Education's Center for Professional Development may use the results in planning curriculum for the Principals' Academy, 
in which principals of schools not earning full approval must enroll. The state legislature may use information concluded from this study in delineating standards of school accreditation and in establishing professional development requirements for school leaders. Data gathered through this inquiry will be shared with superintendents in the fifty-five county school systems of West Virginia and the West Virginia Performance Based Accreditation System.

\section{LIMITATIONS}

Conclusions reached through this inquiry are limited to elementary schools in West Virginia. However, there are many additional limitations related to both the internal and external validity of this study as well. Because the random sample of fully accredited schools was selected only from elementary schools within the state, data will be limited to that population and cannot be generalized to other geographic areas or schools composed of other grade level configurations. Response bias (Kerlinger, 1986) may be a limitation due to the limited population sample of schools lacking full accreditation status verses those schools receiving full accreditation status. Instrumentation may also be a limitation in this study. Teachers self-administered the instrument, and the conditions in which self-administration occurred were not controlled.

Certain extraneous variables, such as demographic data and the ability of students, cannot be controlled (Kerlinger, 1986). The Hawthorne Effect, (Campbell \& Stanley, 1963) which indicates that when subjects know they are participating in a research study, and therefore perform as they perceive to be desirable, may also be a limitation. In addition, the inquiry assesses climate through teacher perception, a valid measure of school climate (Halpin \& Croft, 1962); however, factors are related, in a certain sense, to leader behaviors which may result in either inflated or deflated perceptions that could be a result of personalities and positions 
involved. Finally, possible cultural biases may exist on achievement tests which were used to measure school accreditation status.

\section{SUMMARY}

Numerous inquiries have indicated that a significant relationship exists between school climate and student achievement. Student achievement primarily determines state accreditation status in West Virginia public schools. Leadership has been identified as a factor that influences school climate. Although various leadership theories have been tested through numerous inquiries, indications have consistently identified leadership behavior as being related to school

climate. School climate was observed in 53 randomly selected elementary schools which received full accreditation status and in 47 elementary schools which lacked full accreditation status, based on 1998 SAT-9 results. Specific demographic data, the socioeconomic status of students and school size, have also been identified as independent variables in this study.

This inquiry attempted to identify teacher perceived school climate and its relationship, if any, to school accreditation. The CFK, Ltd. School Climate Profile was used. Due to the current method of accrediting schools within the state, this inquiry may provide schools with an abundance of information in improving accreditation status. 


\section{Chapter Two}

\section{LITERATURE REVIEW}

\section{Introduction}

An abundance of literature indicates that a relationship exists between school climate and student achievement, with climate being influenced by principal behaviors within the school. The socioeconomic status (SES) of students enrolled in a given school and the school size (enrollment) have also appeared in the literature as factors which have impact upon student achievement. Student achievement, measured through norm-referenced tests such as the Stanford Achievement Test, Ninth Edition (SAT-9), sometimes serve as the basis for school accreditation. Such is the case in West Virginia public schools in which fifty percent of the students enrolled in grades three through eleven must score within the upper two quartiles, and beginning with spring 1999 testing, no greater than fifteen percent of the students may fall within the bottom quartile on the specific achievement test.

School accreditation is also based upon student attendance in West Virginia public schools, student dropout rate, and passage of the rigorous state on-site review process. However, baseline accreditation status achieved as a result of spring 1997, SAT-9 test results verified that all elementary schools not receiving full accreditation status did so because fewer than fifty percent of the students tested in grades three through four or five, but not greater than sixth grade, scored within the upper two quartiles.

In 1998, 47 elementary schools lacked full accreditation status due to SAT-9 test results and seven lacked full accreditation due to noncompliance discovered during the state on-site review process. One of the seven schools also lacked full accreditation status due to SAT-9 test results. 
The school was included in the sample of 47 schools.

Literature associated with the independent variables of school climate, SES, and school size will be reviewed in this chapter. Because school accreditation is based upon student achievement, and student achievement defines an effective school (Chrispeels, 1990), literature associated with effective schools will be included in this chapter.

\section{Climate}

School climate is defined many ways (Anderson, 1992; Bailey, 1988; Drake, 1997; Fox, 1973; Halpin and Croft, 1963; Hoy and Miskel, 1987; Kelley, 1980; Sackney, 1988; Tagiuri, 1968). While definitions of school climate vary, recent literature consistently indicated that behaviors demonstrated by the school leader have a direct influence upon the climate of the school (Al-Gasim, 1991; Almond, 1993; Bailey, 1988; Dickson, 1991; Edwards, 1994; Jackson, 1997; Johnson, 1991; Rasmussen, 1995; Sellers, 1984; Stockton, 1997; Stueven, 1985; Villani, 1996; Williams, 1980), and that school climate may be related to student achievement (Almond, 1993; Edmonds, 1978; Gentile, 1997; Jackson, 1997; Madden, 1976; Rasmussen, 1995; State of New York, 1974; Stockton, 1997; Vardett (1998); Woods, 1998).

Drake (1997) described climate as the tone of the building, the feelings one has while inside the building, and the order of things. The climate attributes identified by Drake indicated that staff morale and dedication play a necessary role in student achievement. Climate factors identified in Drake's (1997) qualitative inquiry were found to be related to student achievement.

Researchers (Bailey, 1988; Kelly, 1980) have stated that school climate is a shared pattern of characteristics formed by the norms, beliefs, and attitudes reflected in the conditions, events, and practices of the specific environment. Bailey (1988) determined through the completion of the 
$\underline{\text { Leader Effectiveness and Adaptability Description - Other (LEAD-Other) and Charles F. }}$

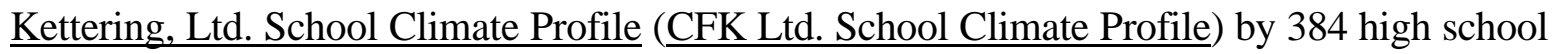
teachers in West Virginia public schools, that climate is positively or negatively associated with the leadership style of the principal as perceived by teachers. Halpin and Croft (1963) defined organizational climate as the perceptions held by members of the organization. High school teachers in West Virginia who perceived their building principals as S4 (low direction, low support) leaders perceived their school climate as negative (Bailey, 1988). Teachers who perceived the leadership styles of their principals as S1 (high direction, low support), S2 (high direction, high support), S3 (low direction, high support), or a combination of these as well as a combination of S3/S4, perceived their school climates as positive (Bailey, 1988). Climate was perceived as highest by high school teachers in West Virginia when the dominant leadership style of the principal was perceived as S2 (Bailey, 1988).

Like Bailey, Stueven (1985), Sellers (1984), and Dickson (1991) also utilized the LEAD

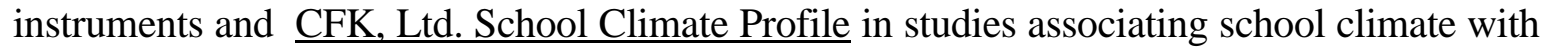
leader behavior. Stueven (1985) determined that school climate was rated more positive in Jefferson County, Colorado, public schools when there was agreement between the type of leadership style preferred by the teacher and the type of leadership style displayed by the principal, as perceived by the teacher. Stueven's findings indicated that it was not the actual leadership style of the principal, but the agreement between teacher preferred and teacher perceived leadership styles of those in school leadership positions that impacted teacher perception of school climate. Like Stueven, Dickson (1991) found that teachers in four Oklahoma school districts rated the school climate less positive when a discrepancy existed between the teacher perceived and teacher 
preferred leadership style of the principal. On the other hand, Sellers's (1984) findings did indicate that a significant correlation between the leadership style of school principals and the school climate did exist. Seller's inquiry took place in Oklahoma elementary and secondary schools.

Stockton (1997) concluded that teachers and parents in Louisiana schools had a significantly higher perception of school climate and greater parent involvement in schools with principals demonstrating more supportive than directive behaviors. Unlike Bailey's (1988) conclusion, climate and parent involvement were perceived as highest in the schools of S3 leaders.

To achieve the status of Blue Ribbon School, a school must be effective in regard to student achievement and total school effectiveness. Knab (1998) determined, through the application of the Leadership Practices Inventory (LPI), that principals of Blue Ribbon Schools scored significantly higher in the visionary category Inspiring a Shared Vision and the empowerment category Challenging the Process and Enabling Others to Act than principals of randomly selected non-Blue Ribbon Schools. Factors determined significant by Knab are consistent with climate factors identified through the CFK, Ltd. School Climate Profile.

In Hail District Saudi Arabia, Al-Gasim (1991) detected a correlation between teacher perceived middle school climate and administrators scoring high in both consideration and initiating structure; both leadership categories were directly related to climate factors identified by the CFK, Ltd. School Climate Profile. Likewise, Williams (1980) concluded that school climate was viewed as being more positive when principals in Madison and Milwaukee school districts were perceived as being high in both initiating structure and consideration behaviors. Accordingly, seventy percent of correlations in Jackson's 1997 inquiry indicated a relationship 
between school climate and leader behaviors as measured by the Leader Behavior Description Questionnaire (LBDQ) and OCDQ in ten Mississippi high schools.

Wood (1998) identified a productive school climate as a climate which included eight effective school correlates that were related to leadership behaviors. Woods's inquiry occurred in an Arizona elementary school considered "unusually effective." Almond (1993) also identified school climate as being related to leadership behaviors in 106 Alabama elementary schools. Almond reported that a significant difference occurred between principal behaviors of schools rated effective by district superintendents and schools rated less effective by district superintendents. Principals in the schools rated as being more effective by district superintendents exhibited behaviors indicating a more positive school climate than principals rated as less effective by district superintendents. Onyeri (1988) also found that the leadership style of the principal was positively and significantly related to school climate in specific schools.

Likewise, Withrow (1993), Robinson (1996), Depasquale (1996), Houseknecht (1990), and Ausejo (1983) reported a significant correlation between leader behaviors and school climate. Ausejo (1983) and Houseknecht (1990) found that a significant relationship existed between leader behaviors and the climate factor, high morale. Depasquale (1996) determined that a very high correlation existed between leader behaviors and the climate factor, trust.

Consistent with this inquiry, Rasmussen's (1995) inquiry was based upon previous research which tied leader behavior to school climate. Rasmussen determined that teacher absenteeism was highest in teachers who viewed school climate less positively than those with low rates of absenteeism. Teacher absenteeism may clearly have an impact upon student achievement, and therefore upon the accreditation status of a school. Rasmussen (1995) developed a research 
instrument to measure the climate factor, high morale. However, numerous instruments are available for use in measuring school and organizational climate.

\section{$\underline{\text { Measuring Climate }}$}

Based on behaviors encompassed by the various accepted theories of leadership, a plethora of research indicates that specific task-oriented and relationship-oriented behaviors relate to school climate (Al-Gasim, 1991; Ausejo, 1983; Bailey, 1988; Jackson, 1997; Johnson, 1991; Rasmussen, 1995; Sellers, 1984; Stockton, 1997; Villani, 1996; Williams, 1980). The CFK, Ltd.

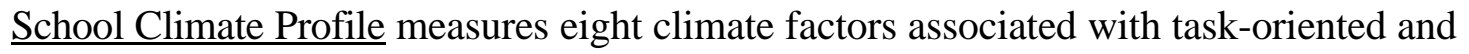
relationship-oriented leadership behaviors (Bailey, 1988). Climate factors are respect, trust, high morale, opportunity for input, continuous academic and social growth, cohesiveness, school renewal, and caring (Bailey, 1988). Climate refers to a concern for both productivity and satisfaction as well as the relationship which exists between the two dimensions (Bailey, 1988). The eight characteristics of the managerial systems method of defining climate (Likert, 1961) were developed as an indicator of superordinate-subordinate relationships. Likert's instrument was the predecessor to the climate factors identified by the CFK Ltd. School Climate Profile. Factors addressed by Likert through the Profile of Organizational Characteristics (POC) included the leadership process, motivational forces, communication process, interaction-influence process, decision-making process, goal setting, control processes, and performance goals and training (Likert, 1961; Bailey, 1988).

As previously stated, the content validity of the CFK Ltd. School Climate Profile was determined by a panel of twelve experts who then constructed the instrument items (Fox, et. al., 1973). The construct validity and reliability of the CFK Ltd. School Climate Profile was 
determined by an additional panel of expert judges (Dennis, 1979) and both were found to be extremely high. The construct validity was found to be .86 , and the reliability was determined as .98 (Dennis, 1979).

Villani (1996) concluded that the traits of strength (masculinity, dominance) and security (self confidence) in the principal were related to school effectiveness whether the climate was open or closed. Villani concluded that strength and security, as identified through the interview process, impacted on the leadership behaviors of the principal in determining school climate. Utilizing the Occupational Climate Descriptive Questionnaire (OCDQ) and Least Preferred Coworker (LPC), Edwards (1994) deduced that a relationship existed between leader style and the climate factors of supportiveness and intimacy. Both factors are characteristics of an open climate, as defined by the OCDQ.

Halpin and Croft developed the OCDQ at Ohio State University in 1962. As stated in the previous chapter, Halpin and Croft (1963) allege that "personality is to the individual what climate is to the organization" (p. 1). Halpin and Croft are among the most renowned researchers in the area of organizational climate. Halpin and Croft (1962) have defined climate as being analogous to the school's personality and state that climate can be defined by the perception held by group members. The OCDQ measures school climate based on staff perception with members of the organizational staff completing the survey (Sackney, 1988). The OCDQ is made-up of eight subtests used to map the climate profile of a school, but six climate types are identified through the OCDQ. The six climate types are: autonomous, controlled, familiar, paternal, closed, and open. Validity studies have indicated that the subtests are more predictive of the school's climate than the overall climate categories (Sackney, 1988). Furthermore, apart from the open and closed 
climate classifications, the other four classifications have been questioned in regard to validity (Sackney, 1988). The OCDQ, a major school climate instrument, was initially developed for use in elementary schools (Sackney, 1988). Subsequent validity studies have questioned its use in larger high schools.

Sackney (1988) summarized climate, based on definitions by Anderson (1982), Hoy and Miskel (1987), and Tagiuri (1968), as "a relative enduring quality of the internal environment of a school that: is experienced by all members of the school, influences the behavior of the members, is represented in terms of values, norms, and beliefs that impact institutional patterns and behavioral practices that enhance or impede student achievement."

Anderson (1982) believed that school climate was the "stepchild" of both organizational climate research and school effectiveness research, and was often referred to as school improvement or school development. Anderson surmised that researchers in the area of school climate inherited instruments, theory, and methods from both paradigms of research. Even though the relationship exists, Anderson argued that school climate can be differentiated as a separate entity. Dimensions of school climate, according to Anderson, are based upon the climate taxonomy developed by Tagiuri (1968).

The total environmental quality within an organization, according to Tagiuri (1968), includes the dimensions of milieu (the social dimension of people), ecology (the physical and material components), and culture (the belief systems, values, cognitive structures, and meanings). Tagiuri's system is preferred by Anderson (1982) because it is said to reflect the growing consensus among many climate researchers that climate includes the total environmental quality within any given school. Hoy and Miskel's (1987) definition is similar to that of Anderson and 
Tagiuri. Hoy and Miskel reported that school climate is a set of internal characteristics that distinguish one school from another and that climate is an end product of the school. People within a particular climate experience and share certain values, social beliefs, and social norms. The values, beliefs, and norms can be positive or negative, productive or counter-productive.

In addition to the $\underline{\mathrm{CFK}}$, Ltd. School Climate Profile, POC, and OCDQ, additional instruments briefly discussed in chapter one of this inquiry exist in order to measure school climate. The Pupil-Control Ideology (PCI) was developed by Willover, Eidell, and Hoy in 1967.

The PCI postulated a pupil-control continuum to measure climate. The continuum ranged from custodial to humanistic and was comprised of 20 items. Using a Likert-type scale, teachers completed the PCI to determine if the given school implemented a custodial orientation which favored a controlled, impersonal, and order-oriented environment or a humanistic orientation which operated from an interactive, self-disciplined, and communicative mode of practice (Sackney, 1988). A strength of the PCI, according to Hoy and Miskel (1982) was that it allowed for an alternate view of school climate which focused on teacher-student relations rather than teacher-teacher and principal-teacher relations. Like the OCQD and POC, the PCI is a major school climate instrument (Sackney, 1988).

An additional view of school climate rests in the classroom context (Anderson, 1982; Sackney, 1988). In the late 1960s, a number of researchers peered into the classroom for a perspective on school climate. Instruments developed as a result of Murray's (1938) theoretical work with environmental press were related to the classroom context and included the $\underline{\text { Classroom }}$ $\underline{\text { Environmental Scale }}$ (CES), the Learning Environment Inventory (LEI), and My Class Inventory (MCI), which then paved the way for the needs-press type instrument, My School Inventory 
(MSI). Press is the perceptions, values, and attitudes which derive the school profile (Sackney, 1998). Based on the school profile, needs are distinguished through use of the identified instruments. Other instruments developed based on the needs-press context (Sackney, 1988) included the High School Characteristics Index (HSCI) used to measure press in high schools, the Elementary School Environment Survey (ESES), and the Quality of School Life (OCL). Many schools use modified versions of the OCL to include the perspective of students as do the MCI, MSI, HSCI, ESES, and OCL.

Regardless of the instrument used to measure climate, the significance lies in the potential relationship between school climate and student achievement, which categorizes a school as effective. Effective schools are schools in which students from all socioeconomic backgrounds score at comparable levels on standardized achievement tests (Chrispeels, 1990). Effective schools possess a positive school climate and culture as well as high expectations for all students (Chrispeels, 1990).

\section{$\underline{\text { Socioeconomic Status }}$}

As early as 1966, Coleman reported that the socioeconomic status (SES) of students was an indicator of student achievement. Coleman indicated that no factors associated with the school itself could improve academic achievement. While numerous studies have rebutted Coleman's evidence in relation to student achievement, SES has been identified as an indicator of pupil success on standardized achievement tests nationwide (Howley, 1996; Finklea, 1997; McKee, 1996; Peach, 1996; Summers, 1992; Surya, 1994; Schwaninger, 1997; Watts, 1996).

In addition to leadership behaviors, Finklea (1997) also concluded that student SES was

related to school effectiveness. A high negative correlation was found to exist between SES and 
the variables of school effectiveness. Finklea (1997) recommended that the socioeconomic status of students enrolled in schools be considered when interpreting data related to school performance.

Likewise, Schwaninger (1997) appraised that group differences occurred on the Iowa Test of Basic Skills between students of low SES and high SES. Students of low SES scored lower on the achievement test than students of high SES. Consistent with Finklea and Schwaninger, Peach (1996) found a consistent difference between the mean Missouri Mastery and Achievement Test (MMAT) scores in reading for students of low SES and non-low SES. Student mean scores in the non-low SES group were 20 or more points higher in seven of eight reading tests and higher in mathematics, indicating significant statistical differences.

Continuing the aforementioned trend, Watts (1997), Jones (1996), Griffin (1996), Surya (1994), and McKee (1996) also extrapolated that a relationship existed between SES and student achievement. Watts (1997) deduced that a strong relationship existed between SES and student achievement in West Virginia elementary schools. Surya's (1994) results denoted that student achievement appeared lower in low SES groups of schools than in high SES groups of schools in Pennsylvania according to scores on the Test of Essential Learning and Literacy Skills (TELLS), a state-mandated test for every school district in Pennsylvania. Griffin (1996) classified schools as exemplary or developing, with exemplary schools demonstrating greater student achievement on standardized tests. Developing schools demonstrated a significantly greater population of students eligible to receive free or reduced lunch, indicating low SES, and a greater minority population than exemplary schools.

Clarke (1997), on the other hand, found no significance between SES and student 
performance but did conclude that a significant relationship existed between family structure and student achievement.

McKee (1996) discovered that not only did SES affect student achievement, but school size and ethnicity impacted student achievement as well. Students who paid for their lunch scored higher than students receiving free lunch regardless of school size and ethnicity. African American students at larger schools scored higher in math and reading than African American students in smaller schools. In larger schools only, there was no significant difference in math and reading scores of African American students, Hispanic students, and Caucasian students.

Based on the conclusions of the numerous inquiries cited, it does appear that the socioeconomic status of students may have an impact upon student achievement, and therefore on the accreditation status of schools within West Virginia.

\section{$\underline{\text { School Size }}$}

"In America, big has long been a synonym for better... Schools have not been immune to the American fascination with bigness. Individuals want bigger cars, houses, paychecks, and schools" (Stevenson and Pellicer, 1998, p. 18). The consolidation of small schools into larger ones has been identified as a way for schools to operate more economically and increase academic opportunities through specialization (Stevenson and Pellicer, 1998). Economies of scale are said to enable school districts to take advantage of larger numbers to become more economically feasible. Small schools are considered costly to operate. When a limited number of students is being served, the facility must continue to be maintained whether 50 or 150 students are enrolled.

The West Virginia School Building Authority (SBA) in chapter one of the handbook, Guidelines and Procedures of the School Building Authority (West Virginia Department of 
Education, 1999) defined economies of scale as follows: "Economies of scale include compatibility with similar schools that have achieved the most economical organization, faculty utilization and pupil-teacher ratios." To receive funding from the SBA, the district plans for school construction must meet the economies of scale based on the minimal allowable enrollment to receive construction funds. Minimum allowable enrollments in elementary schools serving students in grades 1-6 are 300 with a minimum of two classes ( 25 students) per grade level and 200 students in grades $1-4$ with a minimum of two classes ( 25 students) per grade level. Early childhood, kindergarten, and special education may increase the minimum standard. However, funding may be considered if evidence in planning suggests $85 \%$ of building capacity will be maintained. This would allow a minimum of 22 students per class in the elementary grades 1-6. The economies of scale (EOS) established by the SBA is not a definition of small or large regarding school size. The EOS are designed to determine funding for school construction projects based upon maintaining $85 \%$ of the minimum allowable enrollment.

Howley (1996) utilized the SBA definition and interpreted an elementary school with 50 pupils per grade level as the minimum allowable school size. Howley reported that the terms "smaller" and "larger" were relative because all variables were measured continuously. While no definition of small and large existed in Howley's (1996) analysis, the researcher stated that many schools not meeting the SBA's economies of scale had been closed in West Virginia by 1994. Although no definition of large and small was stated, it was implied that schools not meeting the economies of scale may be considered small.

Although conclusions reached through Howley's (1996) investigation indicated that smaller schools benefitted impoverished children and larger schools benefitted affluent children, the 
researcher's measure of school size, whether it be large or small, was not determined through actual enrollment figures for entire schools. Howley determined school size based on 1990 cohort groups at the elementary grade levels three and six. At the time of data collection, the Comprehensive Test of Basic Skills (CTBS) was administered to all students in West Virginia enrolled in the third and sixth grades. School size was defined as the fall 1990 enrollment in the grade level cohort. For example, if third grade was the identified cohort group and there were 15 students enrolled in the third grade, then the enrollment of each grade level in the school was calculated to be 15 students. In a school housing grade levels kindergarten through fourth grade, the enrollment would have been reported as 75 students. Howley (1996) stated that this practice is common in school size studies because it controls for the effects of different grade level configurations of schools.

Size was also determined by cohort groups at the county district level. One entire county school district in West Virginia was excluded from the Howley (1996) investigation. Due to a large portion of the state's student population being enrolled in Kanawha County schools, Kanawha County was excluded from the research findings because it was identified an outlier in box plot analysis (Howley, 1996). Howley ascertained that small schools should be retained in impoverished communities, and that reorganizing West Virginia's 55 county districts into multicounty districts in order to provide larger schools was a "bad idea." Howley (1996) concluded that school consolidation did not foster school improvement.

In an earlier study, Howley (1989) noted that when SES was controlled, "small scale schooling seems to provide substantial benefits to students in poor and working-class communities" (p. 8). Unlike Howley's West Virginia findings, Arnold (1996) reported that 
children attending smaller, rural schools in Michigan had access to lower quality professional staffs and achieved at lower levels than children in other types of school districts.

Stevenson \& Pellicer (1998) synthesized findings by numerous researchers to conclude that although small schools can "claim" advantages such as a more intimate and caring atmosphere, large schools can boast specialized teaching and a more optimal curricula. However, Stevenson and Pellicer (1998) also reported that there is no optimal school size, and that well-trained, dedicated teachers, visionary leaders, involved parents, and supportive communities are essential. Stemnock (1974) found no differences in achievement between small and large schools. Likewise, McGuffey (1991) reported that in Georgia schools, no difference in achievement was indicated where school size was concerned and SES was controlled. Lamdin (1995) reported that school size had no effect upon student achievement in Baltimore schools.

Stevenson (1996) conducted a state-wide study of South Carolina elementary schools to find that while there are clear arguments for both large and small schools, when control was provided for SES larger schools were identified as demonstrating better academic performance by students than smaller schools according to recognition by state departments of education and national organizations.

While Maiden and Foreman (1998) did not specifically address school size, the researchers did report that a school building's condition has been identified as affecting student achievement. Often, larger consolidated schools are newly built or renovated since existing ones have to be enlarged to include students from other schools. Perhaps the condition of the facility and not necessarily the school size results in greater student achievement. Earthman and Lemasters (1996) ascertained similar indications that the physical facility and school size impacted student 
achievement and behavior, perhaps sending the subtle message to children that education is important and the students are worthy of learning in a modern and well-equipped facility.

A relevant and mathematical relationship exists between school size and accreditation status within West Virginia schools. In large schools, there are more students and therefore a greater number of students may score within the bottom quartile on the achievement test. For example, a large school in which 500 students complete the Stanford Achievement Test must demonstrate that 250 students score above the fiftieth percentile. If 250 students score within the upper two quartiles, as indicated, then up to 75 students could score within the bottom quartile, beginning with spring 1999 student testing, and the school would still receive full accreditation approval. A school in which 100 students are tested must demonstrate that 50 students score within the upper two quartiles, with a minimum of 15 students scoring within the bottom quartile.

\section{$\underline{\text { School Accreditation Status }}$}

The Performance Based Accreditation System that became law on July 14, 1988, requires a collaborative approach to improving education in West Virginia. W. Va. Code §18-2E-5 mandates that the West Virginia Board of Education establish a schedule and review each school within a district and each county board of education for accreditation. (Marockie, 1997, p. ii)

According to West Virginia Code §18-2E-5 which led to West Virginia Board of Education Policy 2320, Performance Based Accreditation System, it is clear that the accreditation of schools and school districts within the state of West Virginia is mandated by law. The West Virginia Performance Based Accreditation System began during the 1989-90 school year and continues to monitor public schools annually. 
As a result of 1998, House Bill 4306, revisions have been made to Policy 2320, Performance Based Accreditation System. Policy 2320 (1998) includes the following provisions relating to this inquiry.

The term temporary accreditation status has replaced probationary accreditation status (§126-13-7). Schools not meeting the previously discussed established performance measures and receiving temporary accreditation status then have the opportunity to revise the unified school improvement plan. The revised plan must include objectives, a time line for evaluation of the success of the improvements, estimated costs, and a certain date when full accreditation status can be achieved. The revised plan results in conditional accreditation status with a goal of receiving full accreditation status by an identified future date. If the school on conditional accreditation status fails to meet the objectives and time line required under conditional approval, that school then becomes "seriously impaired" (§126-13-7). Whenever a school is seriously impaired, an improvement team is to be appointed by the State Board of Education to make immediate recommendations for improvement. If the school fails to improve its status within one year, the school then receives non-approval (§126-13-7). Students attending non-approved schools may transfer, at the expense of the school from which they are transferring, to the nearest fullyaccredited school.

Schools in which the total basic skills score for one or more grade levels in grades three through eleven falls below the thirtieth percentile in the most recent year and in one of the two preceding years is considered seriously impaired. Seriously impaired status is also earned if the school attendance rate is at or below eighty percent in two out of three consecutive years and if the dropout rate is at or above ninety percent in two out of three consecutive years. Schools may 
also become seriously impaired when extraordinary circumstances, such as failure of the state onsite review, exist (\$126-13-7).

County school systems with the state of West Virginia receive full approval when all of its schools have been issued temporary, conditional, or full accreditation status (§126-13-8).

Therefore, if one school fails to meet the objectives and time line necessary to achieve approval and becomes seriously impaired, the school system may also receive seriously impaired status or non-approval status (§126-13-8). Seriously impaired status or non-approval may be issued for other reasons as well.

Due to the high quality standards established by the state of West Virginia, it is imperative that student achievement meets or exceeds the minimum levels set forth in Policy 2320. Failure to do so may bear grave consequences for schools and school districts. Foregoing studies indicate the importance of school climate in regard to its relationship with student achievement (Almond, 1993; Chrispeels, 1990; Cordero, 1996; Edmond, 1978; Finklea, 1997; Gentile, 1997; Hoy and Hannum, 1997; Jackson, 1997; LeMasters, 1997; Madden, 1976; McDonald-Risik, 1997; Rasmussen, 1995; Stroud, 1993; State of New York, 1974; Stockton, 1997; Traufler, 1992; Vardett, 1998; Watts, 1997; Woods, 1998; Zielke, 1989), and therefore its impact upon the accreditation status of schools.

\section{Climate and School Accreditation}

While it is not certain whether various school climates produce different student outcomes (Sackney, 1988), the literature does indicate that the effectiveness of schools in terms of student achievement is influenced by the quality of the school climate. School effectiveness is not a new area of inquiry for researchers. Studies relating to the effectiveness of schools date back to the 
1950s and 1960s. Coleman (1966) found no significant relationship between input variables such as the school's physical plant, extracurricular activities offered, quantities of resources available, and characteristics of the principal and teachers and student achievement. Coleman (1966) did, however, conclude that a high correlation existed between student socioeconomic status and pupil performance. Through his conclusions, Coleman indicated that student achievement was an exclusive function of family background.

As a result of Coleman's report, which led to much debate among educators and researchers questioning the impact schools could have upon student achievement, the trend in variables shifted (Bailey, 1988). Throughout the 1950s and 1960s, variables most often studied were input and output variables such as those previously mentioned. As the debate over Coleman's findings subsided, the variables shifted to process and outcome variables rather than input-output variables (Bailey, 1988).

Weber (1971) published Inner-City Children Can be Taught to Read: Four Successful

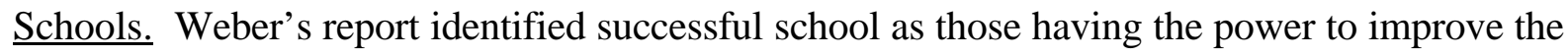
reading achievement levels of third grade students. In those schools, Weber determined the following: Specific emphasis was placed upon reading instruction; Frequent and careful monitoring of student progress occurred; A pleasant, orderly, and quiet atmosphere existed, and school administrators set the tone for the school and took responsibility for instruction and allocation of resources necessary to meet the goals established by the school (Weber, 1971). Likewise, researchers in the state of New York (1974) conducted an investigation in which leadership behaviors and the school environment significantly impacted student achievement test scores. Student achievement appeared to be directly related to factors under the control of the 
school (State of New York, 1974). Leadership behaviors and an atmosphere conducive to learning appeared in inquiries by Madden (1976), Edmond (1978), and Brookover (1979) as well.

Stroud (1993) ascertained that National School of Excellence and Blue Ribbon Recipient, Clay County Junior High School located in rural Clay County, West Virginia, reflected the criteria fundamental to the Blue Ribbon Schools Program. Criteria overwhelmingly indicated the presence of effective school characteristics, especially the characteristics of school climate and leadership.

In a South Carolina inquiry Traufler (1992) determined that a relationship existed between the six correlates of effective schools identified by the South Carolina Department of Education and student achievement measured by fourth grade student scores on the Stanford Achievement Test, Eighth Edition. Among the six correlates of effective schools was a positive school climate. The most significant of the six correlates as a predictor of student achievement, however, was home/school relations. Likewise, Cordero (1996) concluded that Limited English Proficient (LEP) students in New York City schools experienced greater achievement in mathematics, measured by the Metropolitan Achievement Test of Mathematics and the New York State Pupil Evaluation Test, when four school effectiveness characteristics were present. School Effectiveness Characteristics identified were teacher and staff effectiveness, administrative leadership, the planning process, and a positive school climate. Like Traufler (1992) and Cordero (1996), LeMasters (1997) and Hoy and Hannum (1997) deemed that school climate was among factors contributing to student achievement. In a synthesis of 53 research studies spanning 17 years, LeMasters (1997) concluded that climate did indeed impact student achievement. Hoy and 
Hannum (1997) reported that even though the concept of climate is difficult to define and measure, organizational health dimensions were significantly related to student achievement in New Jersey middle schools.

The CFK School Climate Profile measures caring as one aspect of school climate. Voelkl (1995) defined school warmth as the degree of teacher warmth, caring, and supportiveness as perceived by the student. Conclusions of Voelkl's analysis indicated no significant difference between the degree of school warmth and student achievement.

Thus, it has been indicated through numerous studies that leader behaviors have a definite influence on the climate of a school (Al-Gasim, 1991; Almond, 1993; Ausejo, 1983; Bailey, 1988; Depasquale, 1996; Dickson, 1991; Edwards, 1994; Houseknecht, 1990; Jackson, 1997; Johnson, 1991; Rasmussen, 1995; Robinson, 1996; Sellers, 1984; Villani, 1996; Stockton, 1997; Stueven, 1985; Watts, 1997; Williams, 1980; Withrow, 1993), and it is likely that school climate has an impact upon student achievement (Almond, 1993; Chrispeels, 1990; Cordero, 1996; Edmond, 1978; Finklea, 1997; Gentile, 1997; Hoy and Hannum, 1997; Jackson, 1997; LeMasters, 1997; Madden, 1976; McDonald-Risik, 1997; Rasmussen, 1995; Stroud, 1993; State of New York, 1974; Stockton, 1997; Traufler, 1992; Vardett, 1998; Watts, 1997; Woods, 1998; Zielke, 1989). Student achievement, measured through standardized achievement tests such as the SAT-9, is among criteria necessary for schools and school districts to receive accreditation by organizations such as the West Virginia Performance Based Accreditation System.

\section{Summary}

Recent literature clearly indicates that a relationship exists between leader behaviors and school climate and between school climate and student achievement in districts world-wide. 
Because student achievement is the primary criteria used in granting full accreditation to public schools in West Virginia, it is important that factors which relate to increased student achievement be identified in order for schools to revise improvement plans and achieve or maintain full accreditation status. Schools and school districts which fail to achieve or maintain full accreditation status within a three year period risk non-approval and stringent intervention by the state department of education, thus limiting local control of the education process. The Socioeconomic status of students and school size have also been identified in recent literature as variables related to student achievement, and therefore being related to the accreditation status of schools as well. 
Chapter Three

\section{RESEARCH PROCEDURES}

\section{$\underline{\text { Introduction }}$}

Much research in the field of education is said to be descriptive in nature rather than being true experimental research (Campbell \& Stanley, 1963; Kerlinger, 1986). While the purpose of descriptive research and true experimental research is the same, studies in the category of trueexperimental research have control over the selection of subjects and randomization of the treatment. Studies that are descriptive in nature tend to lack control of subject selection and randomization of the treatment (Kerlinger, 1986). Non-true experimental research requires repetition and cross-validation under other conditions and with other populations to be theoretically interpreted with confidence (Campbell and Stanley, 1963).

In an earlier analysis limited to 29 elementary schools in Boone, Kanawha, Lincoln, and Logan counties in southern West Virginia (Watts, 1997), the researcher investigated variables similar to variables identified in this inquiry and recommended additional study. Utilizing the Organizational Health Inventory for Elementary Schools (OHI-E) and scores earned on the Comprehensive Test of Basic Skills (CTBS) for third and sixth grade students in selected schools, Watts determined that significance existed between variables at the sixth grade level but not at the third grade level. As the school health index increased, so did the achievement levels of sixth grade students on the CTBS.

In the current state-wide analysis involving school climate and school accreditation status, based on student achievement, two populations existed. One population, defined as schools which lacked full state accreditation status due to student achievement test results, was 
predetermined by the school's accreditation status itself. The second group, schools which earned full accreditation status in 1997 and 1998, was randomly selected from 329 elementary schools which earned full accreditation status both years.

The purpose of the current investigation was to determine if a statistically significant difference existed between the mean, teacher-perceived school climate scores in West Virginia elementary schools and the accreditation status of the schools. Also investigated were the mean teacher-perceived school climate scores in conjunction with both the socioeconomic status of schools (SES) and school size, and the difference in state accreditation status between the two groups, those which lacked full accreditation status and those which earned full accreditation status. SES was determined by the percentage of students eligible to receive United States Department of Agriculture (USDA) free and reduced lunch (Finklea, 1997; Howley, 1996; McKee, 1996; Peach, 1996; Summers, 1992; Surya, 1994; Schwaninger, 1997).

\section{$\underline{\text { Design }}$}

This inquiry is a descriptive, "one shot case study" (Campbell and Stanley, 1963) in which the independent variables are identified as teacher-perceived school climate, and teacherperceived school climate together with both the socioeconomic status of schools and school size. The dependent variable is state accreditation status earned by schools through student achievement on the Stanford Achievement Test as reported by the West Virginia Performance Based Accreditation System (Marockie, 1997; 1998).

\section{Population and Sample}

Two populations existed within this inquiry. Populations were (a) three hundred twentynine elementary schools which received full state accreditation status as a result of both 1997 and 
1998 Stanford Achievement Test (SAT-9) results, and (b) forty-seven elementary schools which lacked full state accreditation status as a result of 1998 SAT-9 results. Thirty-one of the 47 schools lacked full accreditation status in both 1997 and 1998, while 16 lacked full status in 1998 only. Six additional elementary schools lacked full status in 1998, but their lack of full accreditation status was due to non-compliance discovered during the state on-site review process. The six schools were omitted from the population in this study as were 61 additional elementary schools which lacked full approval in 1997 but earned full approval in 1998.

The entire population $(\mathrm{N}=47)$ of elementary schools which lacked full accreditation status as a result of 1998, SAT-9 results constitute one sample group. The additional sample group of 53 schools was randomly selected from the remaining population of 329 elementary schools which received full accreditation in both 1997 and 1998 as a result of SAT-9 results. At the time of the study, four hundred forty-three schools existed within the state of West Virginia (Marockie, 1998) and met the definition of elementary school. Elementary school is defined in this study as a school serving students in grades pre-kindergarten or kindergarten through at least fourth grade, but not greater than sixth grade. Elementary schools consisting of other grade level configurations do exist within the state of West Virginia but were not included in this study. 


\section{Figure 1}

Breakdown by population and sample of elementary schools which earned full accreditation status in $1997 \& 1998$ and those which lacked full accreditation in 1998 as reported by The

\section{West Virginia Performance Based Accreditation System}

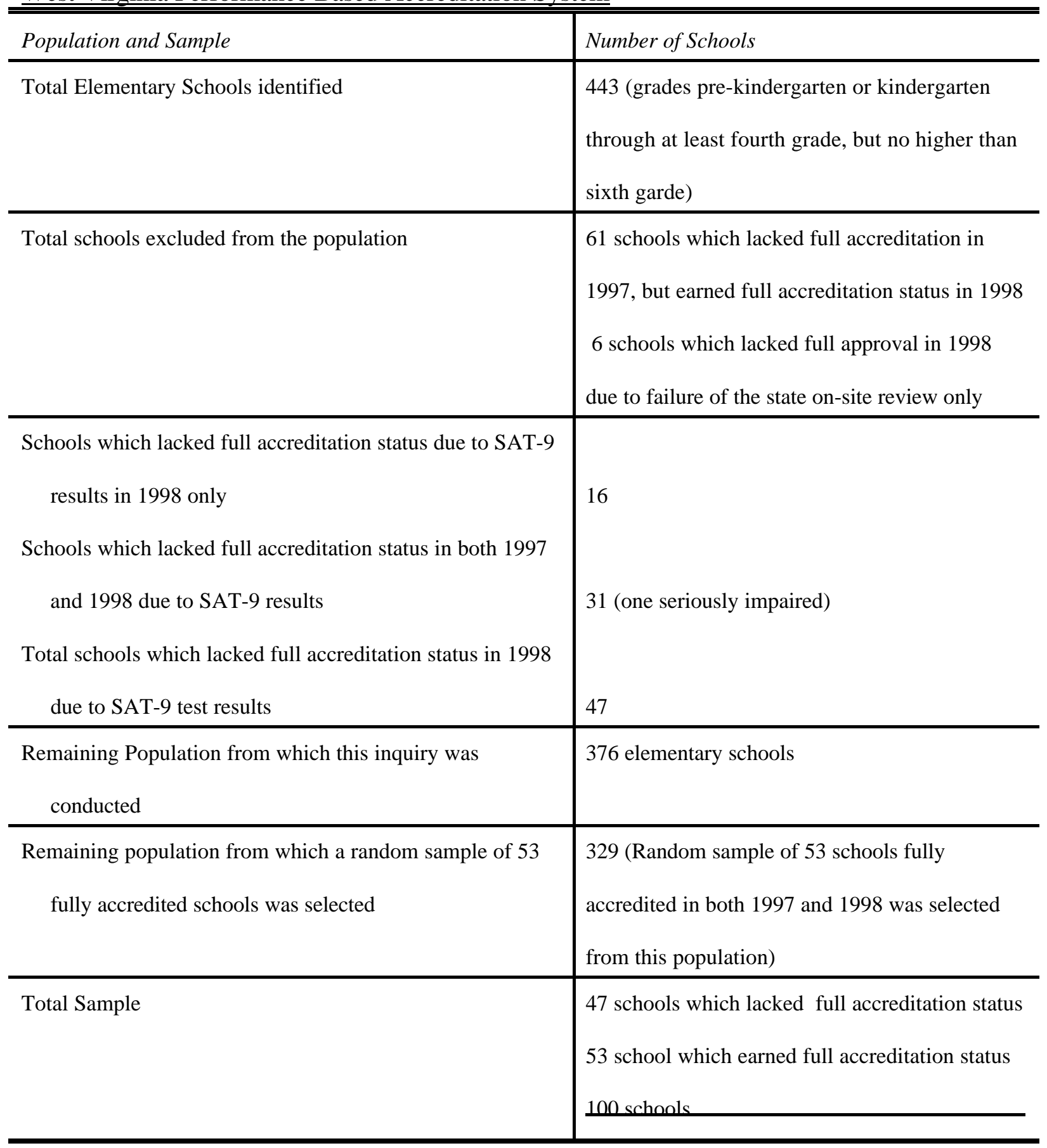




\section{Instrumentation}

One instrument was used in this study. Teacher perceived school climate was measured through individual teacher completion of the Charles F. Kettering Foundation, Ltd. School Climate Profile (CFK School Climate Profile). The SES of schools was measured by the percentage of students eligible to receive USDA free or reduced lunch in each sample school. Data was provided by the West Virginia Department of Education, Office of Child Nutrition. The number of students enrolled in each sample school was also provided by the West Virginia Department of Education, Office of Child Nutrition and was calculated through the West Virginia Education Information System (WVEIS) second month report. Accreditation is defined as the status earned by each sample school and reported through the West Virginia Performance Based Accreditation System (Marockie, 1997; 1998). State accreditation status is a result of achievement test scores, attendance rates, state on-site reviews, and student dropout rates but is limited to student achievement test data in this inquiry.

School climate is defined as the mean score of participant responses on the forty item general climate factors of The CFK School Climate Profile. Eight general climate factors were measured. Climate factors were respect, trust, high morale, opportunity for input, continuous academic and social growth, cohesiveness, school renewal, and caring. Each item which appeared on The CFK School Climate Profile was rated one through four on a Likert scale. The mean score was calculated by totaling the scores on all forty items.

Howard (1987) reported that the content validity of the CFK School Climate Profile was determined by a panel of twelve experts who identified the content areas of school climate. The expert panel then constructed the instrument items (Fox, 1973). Dennis (1979) analyzed the 
construct validity and reliability of the instrument (1979). Both a criterion measure of school climate and ratings from an expert panel of judges determined the construct validity. The construct validity for perception of teachers was determined to be .86 . The reliability of the $\underline{\mathrm{CFK}}$,

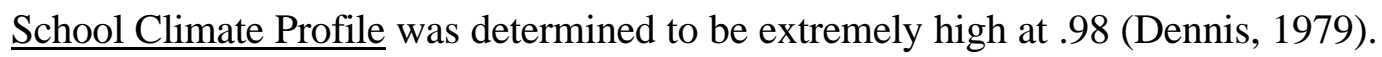

\section{$\underline{\text { Methods }}$}

On February 28, 1999, Faculty Senate Chairpersons in each of the 100 elementary schools included in the study sample were mailed the directions for inquiry participation, copies of the

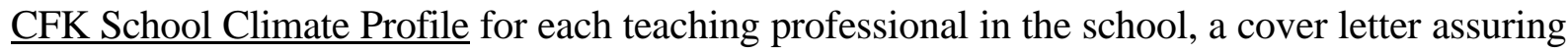
anonymity, and a stamped and addressed return envelope. Faculty Senate Chairpersons were requested to distribute surveys to be completed at the March 1999 Faculty Senate Meeting. Exactly one week later, post cards were mailed to all 100 Faculty Senate Chairpersons to encourage inquiry participation.

An acceptable teacher return rate was determined to be a minimum of eight surveys returned in schools with 15 or more teachers and 50\% of the surveys returned in schools with 14 or fewer teachers. School return rate was determined to be a minimum of $50 \%$ plus one (Kerlinger, 1986). Return rate for this inquiry, which included at least eight or $50 \%$ of the teachers responding per school, was 65\%. Individual school responses have been kept in the strictest confidence.

\section{Data Analysis}

Differences in mean climate scores were calculated through the use of Independent Samples T-Tests and were compared between groups which received full accreditation status and those which lacked full accreditation status. T-Tests were also conducted to compare the mean 
percentage of students eligible to receive free or reduced lunch and school size, based on second month enrollment, between the two accreditation status groups. Stepwise multiple linear regression was also conducted to determine which, if any, independent variables were predictors of the dependent variable, accreditation status. In all statistical tests, an alpha level of $p<.05$ was used.

The Statistical Product Service Solutions (SPSS), Base 9.0 system was utilized in the data analysis. Findings of this inquiry were limited to the identified population, elementary schools within the state of West Virginia. The ability to generalize findings (Kerlinger, 1986) of an inquiry is limited to the population from which the sample is selected. Because the sample was selected only from elementary schools within the state, data will be limited to that population and cannot be generalized to other geographic areas or grade level configurations. Response bias was a limitation due to the limited population size of schools which earned probationary approval in 1998 verses those schools which earned full academic approval.

\section{$\underline{\text { Summary }}$}

This inquiry investigated the relationship between school climate and the accreditation status of elementary schools in West Virginia and between school climate in conjunction with school SES and school size and accreditation status. Faculty Senate Chairpersons in 100 sample schools received copies of the CFK, Ltd. School Climate Profile for each teacher within the sample school to complete in determining teacher perceived school climate. Statistical Product

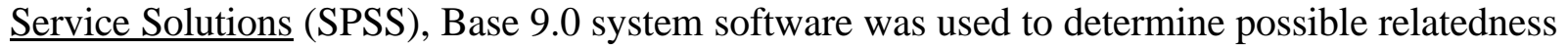
between factors. 


\section{CHAPTER FOUR \\ Presentation and Analysis of Data}

\section{$\underline{\text { Introduction }}$}

The purpose of this study was to determine if a statistically significant difference existed between mean climate scores in elementary schools which earned full accreditation status and those which lacked full accreditation status in the state of West Virginia. The independent variable, teacher perceived school climate, was measured through completion of the 40 item Charles F. Kettering, Ltd., School Climate Profile (CFK School Climate Profile) by 822 elementary teachers from 65 schools. The dependent variable, accreditation status of schools, is granted within the state using student performance on the Stanford Achievement Test, Ninth Edition (SAT-9) as the primary criteria. Other criteria used in granting accreditation status to schools are (a) the school demonstrates acceptable accreditation standards during an on-site review process conducted by representatives of the West Virginia Performance Based Accreditation System, (b) student attendance, (c) drop out rate, and (d) beginning with spring 1999 testing, the percentage of students scoring in the bottom quartile on the SAT-9. The independent variables were the socioeconomic status of the school (SES), based on the percentage of students eligible to receive United States Department of Agriculture (USDA) free and reduced lunch, and school size, determined by the total second month student enrollment reported by West Virginia Department of Education. This chapter includes the following sections. (a) descriptive data, (b) statistical analysis of the data, (c) major findings, (d) ancillary findings, and (e) a chapter summary. 


\section{Descriptive Data}

For purposes of this inquiry, elementary schools have been defined as schools within the state of West Virginia serving students in grades pre-kindergarten or kindergarten through at least fourth grade, but no higher than sixth grade. The West Virginia Education Directory (Marockie, 1998), was used to identify 443 elementary schools.

When the SAT-9 was implemented during spring 1997 testing, more stringent standards for school accreditation had already been established. To earn full accreditation status at least $50 \%$ of students in elementary school grades 3-6 must score within the upper two quartiles on the Stanford Achievement Test. As a result of both 1997 and 1998 testing, 114 elementary schools lacked full accreditation status. Sixty-one of the schools lacked full accreditation status in 1997 but earned full accreditation status as a result of spring 1998 testing. Because the factors which may have led to the group's change in accreditation status were unknown, this group of 61 schools was removed from the population sample, and only 53 schools which lacked full status in 1998 remained. The group of 53 schools which lacked full accreditation status in 1998 included 34 of the original schools which lacked full status in 1997 as well. Nineteen additional schools lacked full accreditation status in 1998, according to the 1998 Report of Ratings issued by the West Virginia Performance Based Accreditation System. Six of the 53 schools, however, lacked full status due only to non-compliance discovered during the state on-site review process and not due to student test results. The six schools were removed from the population sample, and a population sample of 47 elementary schools which lacked full accreditation as a result of spring 1998 student testing remained. Because six schools were removed, a difference in size existed between the two sample groups compared in this inquiry. Prior to removal of the six schools, 53 
elementary schools which earned full accreditation status in both 1997 and 1998 were randomly selected from the remaining population of 329 elementary schools which earned full accreditation status both years.

The socioeconomic status of a school (SES) was defined as the percentage of students in the school who were eligible to receive USDA free and reduced lunch. The percentage of students who were eligible to receive free and reduced lunch ranged from $11 \%$ to $99 \%$ in participating schools. The mean percentage of students eligible to receive free and reduced lunch in schools which lacked full accreditation status was 79\%, and the mean percentage of students eligible to receive free and reduced lunch in schools which earned full accreditation status was $54 \%$. The mean percentage of students eligible to receive free and reduced lunch in both sample groups combined was $66 \%$.

School size, which was based on second month student enrollment, ranged from 68 students to 950 students in responding schools. The mean enrollment in schools which lacked full accreditation status was 215 students, and the mean enrollment in schools which earned full accreditation status was 358 students. The mean enrollment in both sample groups combined was 290 students.

Surveys were mailed via United States Postal Service to Faculty Senate Chairpersons in the 100 sample schools. A survey was included for each teacher listed in the West Virginia Education Directory (Marockie, 1998) in each sample school. Directions included in the packet mailed to Faculty Senate Chairpersons assured anonymity and requested that surveys be distributed and completed at the March 1999, Faculty Senate Meeting. An acceptable teacher return rate was determined to be eight teachers, or $50 \%$ of the teachers per school if eight were 
greater than $50 \%$. An acceptable return rate for schools was determined to be $50 \%$ plus one (51) of the 100 sample schools (Kerlinger, 1989). As indicated in Table 1, eight hundred twenty-two teachers in 65 of 100 schools responded to questions on the CFK School Climate Profile. The $65 \%$ return rate included 31 of 47 schools $(66 \%)$ which lacked full accreditation status. Two hundred ninety-seven teachers responded from the group of 31 schools which lacked full accreditation status.

Thirty-four of 53 schools (64\%) which earned full accreditation status were included in the return of $65 \%$, with 525 teachers from the 34 schools responding to survey questions. Total teachers in the sample was 1,678 . In schools which earned full state accreditation status, 1,049 teachers were listed in the State Education Directory (Marockie, 1998). In schools which lacked full state accreditation status, 629 teachers were listed.

Table 1

$\underline{\text { Accreditation Status, }} \underline{\text { Response }} \underline{\text { Rate, }} \underline{\text { SES, }} \underline{\text { and }} \underline{\text { Size }}$

\begin{tabular}{lllll}
\hline Accreditation Status & School & Total Teacher & Mean SES - (free & Mean Size \\
& Response Rate & Returns & \& reduced lunch) & (students) \\
\hline Schools which lacked full status & $66 \%$ & 297 & $79 \%$ & 215 \\
Schools which were granted full status & $64 \%$ & 525 & $54 \%$ & 358 \\
Combined Groups & $65 \%$ & 822 & $66 \%$ & 290 \\
\hline
\end{tabular}

\section{$\underline{\text { Statistical Analysis of Data }}$}

Data were collected through teacher-completion of the 40 item $\underline{\mathrm{CFK}} \underline{\text { School }} \underline{\text { Climate }}$

Profile. Responses in eight sub-categories were computed to arrive at a mean climate score. The

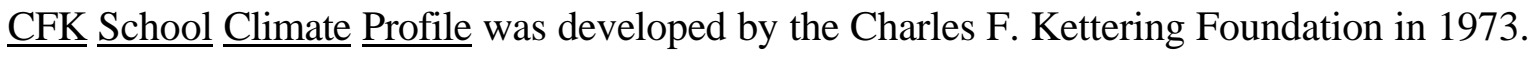


Construct validity for the instrument was determined to be .86 , and reliability of the instrument was determined to be .96 (Fox, 1973). Mean scores in the eight sub-categories determined the overall mean school climate score, as well as the mean climate score in each sub-category. The eight categories included (a) respect, (b) trust, (c) high morale, (d) opportunity for input, (e) continuous academic and social growth, (f) cohesiveness, (g) school renewal, and (h) caring. Data from 822 teachers in the 65 responding schools were computed through the use of Statistical Product Service Solutions (SPSS), base nine, to arrive at an individual school mean for total climate and for each of the eight climate sub-categories. Independent Samples T-tests were conducted to determine if differences in the overall mean climate score and mean scores in each of the eight sub-categories, exhibited in Table 2, were significantly different between schools which lacked full accreditation status and those which earned full accreditation status. Independent Samples T-tests were used to test the equality of group means. 
Table 2

$\underline{\text { Group }} \underline{\text { Statistics }}$

\begin{tabular}{|c|c|c|c|}
\hline Variable & Accreditation Status & $\underline{\mathrm{N}}$ (schools responding) & $\underline{\mathrm{M}}$ (climate scores) \\
\hline \multirow[t]{2}{*}{ Respect } & Full Status & 34 & 17.97 \\
\hline & Lacks Full Status & 31 & 16.99 \\
\hline \multirow[t]{2}{*}{ Trust } & Full Status & 34 & 16.73 \\
\hline & Lacks Full Status & 31 & 15.38 \\
\hline \multirow[t]{2}{*}{ High morale } & Full Status & 34 & 17.42 \\
\hline & Lacks Full Status & 31 & 15.46 \\
\hline \multirow[t]{2}{*}{ Opportunity for Input } & Full Status & 34 & 15.63 \\
\hline & Lacks Full Status & 31 & 14.56 \\
\hline \multirow[t]{2}{*}{ Academic \& Social Growth } & Full Status & 34 & 16.44 \\
\hline & Lacks Full Status & 31 & 15.30 \\
\hline \multirow[t]{2}{*}{ Cohesiveness } & Full Status & 34 & 16.87 \\
\hline & Lacks Full Status & 31 & 15.25 \\
\hline \multirow[t]{2}{*}{ School Renewal } & Full Status & 34 & 16.62 \\
\hline & Lacks Full Status & 31 & 15.31 \\
\hline \multirow[t]{2}{*}{ Caring } & Full Status & 34 & 17.76 \\
\hline & Lacks Full Status & 31 & 16.83 \\
\hline \multirow[t]{2}{*}{ Total Climate } & Full Status & 31 & 135.45 \\
\hline & Lacks Full Status & 34 & 125.09 \\
\hline
\end{tabular}

Regression models were also used in data analysis. Regression models are used to predict outcome variables for a new set of data, to assess how well the dependent variable can be explained by knowing the value of the independent variable or set of independent variables, and to identify which subset of measures is the best predictor for estimating the value of the dependent 
variable.

\section{Major Findings}

An alpha level of .05 was used for all statistical tests $(\mathrm{p}<.05)$. Findings which occurred as a result of this study follow.

Research question 1: What is the relationship, if any, between the teacher-perceived school climate and state accreditation status of elementary schools in West Virginia?

When an Independent Samples T-test was conducted, a significant difference in the overall mean climate score and in seven of the eight climate sub scores existed between elementary schools which lacked full accreditation status and those which earned full accreditation status. Teachers in schools which lacked full accreditation had lower mean scores in overall school climate and in each of the eight climate sub categories. As presented in Table 3, a statistically significant difference existed between the mean scores in overall school climate as well as in seven of the eight sub categories, SES, and school size between the two groups. No significant difference between the mean scores of the two groups existed for the sub category, opportunity for input. The Independent Samples T-test provided no control for the percentage of students who were eligible to receive free and reduced lunch (SES) within schools, nor for school size. 
Table 3

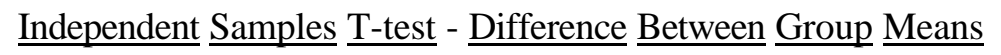

\begin{tabular}{llllr}
\hline Variable & $\underline{\mathrm{t}}$ & $\underline{\mathrm{df}}$ & Sig. (2 tailed) & $\underline{\text { MD }}$ \\
\hline School Size & 3.613 & 63 & $.001 *$ & 142.41 \\
\% Free \& Reduced Lunch & -7.288 & 58.557 & .000 & -24.81 \\
Respect & 2.203 & 63 & $.031^{*}$ & .9768 \\
Trust & 2.883 & 47.895 & .007 & 1.3542 \\
High morale & 4.257 & 63 & $.000^{*}$ & 1.9540 \\
Academic \& Social Growth & 2.357 & 56.458 & .022 & 1.1473 \\
Cohesiveness & 2.976 & 58.665 & .004 & 1.6240 \\
School Renewal & 2.601 & 56.203 & .012 & 1.3078 \\
Caring & 2.058 & 56.691 & .044 & .9315 \\
Total Climate & 2.817 & 54.615 & .007 & 10.3759 \\
\hline Equal Variance Assumed & & & $\mathrm{p}<.05$ &
\end{tabular}

Research question 2: What is the relationship, if any, between the teacher perceived school climate, in conjunction with the socioeconomic status of students, and the state accreditation status of elementary schools in West Virginia?

The socioeconomic status of a school (SES) was defined as the percentage of students in the school who were eligible to receive USDA free or reduced lunch. The SES of schools ranged from $11 \%$ to $99 \%$ in the 65 respondent schools. The mean percentage of students eligible to receive free or reduced lunch was $79 \%$ in schools which lacked full accreditation status and $54 \%$ in schools which earned full accreditation status. The mean percentage of students who were eligible to receive free or reduced lunch in both sample groups combined was 66\%. In all schools which lacked full accreditation status, at least $61 \%$ of the students were eligible to receive free or 
reduced lunch. Only four of the 31 responding schools which lacked full status had less than the mean percentage rate of $66 \%$ eligible to receive free or reduced lunch.

Table 4

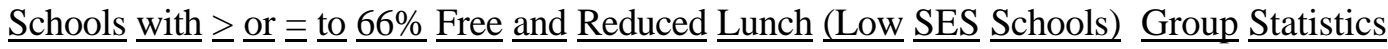

\begin{tabular}{|c|c|c|c|}
\hline Variable & Accreditation Status & $\mathrm{N}$ (schools) & Mean (climate score) \\
\hline \multirow[t]{2}{*}{ Respect } & Full Status & 9 & 18.22 \\
\hline & Lacks Full Status & 27 & 16.83 \\
\hline \multirow[t]{2}{*}{ Trust } & Full Status & 9 & 16.79 \\
\hline & Lacks Full Status & 27 & 15.18 \\
\hline \multirow[t]{2}{*}{ High morale } & Full Status & 9 & 17.01 \\
\hline & Lacks Full Status & 27 & 15.22 \\
\hline \multirow[t]{2}{*}{ Opportunity for Input } & Full Status & 9 & 16.03 \\
\hline & Lacks Full Status & 27 & 14.40 \\
\hline \multirow[t]{2}{*}{ Academic \& Social Growth } & Full Status & 9 & 16.60 \\
\hline & Lacks Full Status & 27 & 15.16 \\
\hline \multirow[t]{2}{*}{ Cohesiveness } & Full Status & 9 & 16.87 \\
\hline & Lacks Full Status & 27 & 14.98 \\
\hline \multirow[t]{2}{*}{ School Renewal } & Full Status & 9 & 16.74 \\
\hline & Lacks Full Status & 27 & 15.08 \\
\hline \multirow[t]{2}{*}{ Caring } & Full Status & 9 & 16.58 \\
\hline & Lacks Full Status & 27 & 17.94 \\
\hline \multirow[t]{2}{*}{ School Size } & Full Status & 9 & 290 \\
\hline & Lacks Full Status & 27 & 200 \\
\hline \multirow[t]{2}{*}{ Total Climate } & Full Status & 9 & 17.94 \\
\hline & Lacks Full Status & 27 & 16.58 \\
\hline
\end{tabular}




\section{$\underline{\text { Low }} \underline{\text { SES Schools }}$}

Schools, in which greater than or equal to $66 \%$ of the students were eligible to receive free or reduced lunch, were identified as low SES schools in this study. As indicated in Table 4, twenty-seven of the 31 responding schools which lacked full accreditation status were low SES schools. Nine of the 34 responding schools which earned full accreditation status were low SES schools.

Contrary to the results indicated through the independent samples t-test in question number one, when the percentage of students who received free and reduced lunch was greater than or equal to $66 \%$, only the teacher-perceived mean scores in the climate sub-categories, respect and high morale as displayed in Table 5, were significantly different between the group which earned full status and the group which lacked full status. When multiple regression analysis was conducted, only high morale, as referenced in Table 6, was identified as a predictor of school accreditation status in low SES schools. In low SES schools, as high morale decreased, analysis indicated the likelihood of earning full accreditation status also decreased. Together the combination of low SES and decreased morale indicated the school would be less likely to earn full state accreditation status.

Table 5

$\underline{\text { Independent }} \underline{\text { Samples }} \underline{T \text {-test for Equality }} \underline{\text { of Means }} \underline{\text { Schools }} \underline{\text { with }}>\underline{\text { or }}=\underline{66 \%} \underline{\text { Free }} \underline{\text { and }} \underline{\text { Reduced }}$ Lunch (Low SES)

\begin{tabular}{lllcl}
\hline Variable & $\underline{\mathrm{t}}$ & $\underline{\mathrm{df}}$ & Sig. (2-tailed) & $\underline{\mathrm{MD}}$ \\
\hline Respect & -2.373 & 30.604 & $.024^{*}$ & -1.3911 \\
High Morale & -2.381 & 17.528 & $.029^{*}$ & -1.7926 \\
\hline * Equal Variance Not Assumed & & $\underline{\mathrm{p}}<.05$ &
\end{tabular}


Table 6

Stepwise Multiple Regression Low SES Schools

\begin{tabular}{llllll}
\hline Variable & $\underline{\mathrm{B}}$ & $\underline{\mathrm{SE}}$ & $\mathrm{Beta}$ & $\underline{\mathrm{t}}$ & Sig. \\
\hline 1 (Constant) & -.755 & .483 & & -1.562 & .128 \\
High morale & 6.412 & .031 & .339 & 2.101 & $* .043$ \\
\hline $\mathrm{p}<.05$ & & & &
\end{tabular}

\section{$\underline{\text { Higher SES Schools }}$}

Schools in which less than $66 \%$ of the students were eligible to receive free and reduced lunch included four of 31 responding schools which lacked full accreditation status and 25 of 34 responding schools which earned full accreditation status, as displayed in Table 7 . When the independent samples t-test was conducted, no significant difference between the mean climate scores was found to exist between the two groups. Due to the limited number of schools which

lacked full status within this group, stepwise multiple regression analysis could not be conducted. 


\section{Table 7}

$\underline{\text { Schools with }}<\underline{66 \%}$ Free and $\underline{\text { Reduced Lunch - Group Statistics }}$

\begin{tabular}{|c|c|c|c|}
\hline Variable & Accreditation Status & $\mathrm{N}$ (schools) & Mean (climate scores) \\
\hline \multirow[t]{2}{*}{ Respect } & Full Status & 25 & 17.87 \\
\hline & Lacks Full Status & 4 & 18.05 \\
\hline \multirow[t]{2}{*}{ Trust } & Full Status & 25 & 16.71 \\
\hline & Lacks Full Status & 4 & 16.70 \\
\hline \multirow[t]{2}{*}{ High Morale } & Full Status & 25 & 17.56 \\
\hline & Lacks Full Status & 4 & 17.09 \\
\hline \multirow[t]{2}{*}{ Opportunity for Input } & Full Status & 25 & 15.49 \\
\hline & Lacks Full Status & 4 & 15.60 \\
\hline \multirow[t]{2}{*}{ Academic \& Social Growth } & Full Status & 25 & 16.39 \\
\hline & Lacks Full Status & 4 & 16.22 \\
\hline \multirow[t]{2}{*}{ Cohesiveness } & Full Status & 25 & 16.87 \\
\hline & Lacks Full Status & 4 & 17.09 \\
\hline \multirow[t]{2}{*}{ School Renewal } & Full Status & 25 & 16.58 \\
\hline & Lacks Full Status & 4 & 16.89 \\
\hline \multirow[t]{2}{*}{ Caring } & Full Status & 25 & 17.70 \\
\hline & Lacks Full Status & 4 & 18.53 \\
\hline \multirow[t]{2}{*}{ School Size } & Full Status & 25 & 382.00 \\
\hline & Lacks Full Status & 4 & 318.25 \\
\hline \multirow[t]{2}{*}{ Total Climate } & Full Status & 25 & 135.18 \\
\hline & Lacks Full Status & 4 & 136.17 \\
\hline
\end{tabular}


Research question 3: What is the relationship, if any, between the teacher perceived school climate, in conjunction with school size, and the state accreditation status of elementary schools in West Virginia?

School size was determined by the number of students enrolled in a school, according to the second month report. School size ranged form 68 students to 950 students. The mean size for schools which lacked full accreditation status was 215 Students. Mean size for schools which earned full accreditation status was 358 students. The mean size for both sample groups combined was 290 students. Schools in which student enrollment was greater than or equal to 290 were identified as large schools. Schools in which student enrolment was less than 290 were identified as small schools in this study.

\section{$\underline{\text { Large Schools }}$}

Table 8 presents findings that in 26 of 65 respondent schools (40\%), student enrollment was greater than or equal to 290. Six of the 26 schools in this category were schools which lacked full accreditation status. Twenty of the 26 schools in this category were schools which earned full accreditation status. Through application of the Independent Samples T-test, no significant difference in mean scores between climate factors and accreditation status was indicated in this group. However, through Independent Samples T-test, presented in Table 9, and stepwise multiple regression analysis, presented in Table 10, the only significant difference between mean scores and the only predictor of accreditation status within this was the percentage of students who were eligible to receive free or reduced lunch. Schools with a higher percentage of students eligible to receive free and reduced lunch (low SES) within this group of large schools 
were more likely to lack full accreditation status.

Table 8

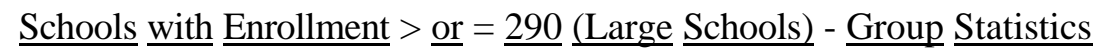

\begin{tabular}{|c|c|c|c|}
\hline Variable & Accreditation Status & $\mathrm{N}$ (schools) & Mean (climate scores) \\
\hline \multirow[t]{2}{*}{ Respect } & Full Status & 20 & 17.58 \\
\hline & Lacks Full Status & 6 & 17.85 \\
\hline \multirow[t]{2}{*}{ Trust } & Full Status & 20 & 16.41 \\
\hline & Lacks Full Status & 6 & 16.65 \\
\hline \multirow[t]{2}{*}{ High Morale } & Full Status & 20 & 17.03 \\
\hline & Lacks Full Status & 6 & 16.92 \\
\hline \multirow[t]{2}{*}{ Opportunity for Input } & Full Status & 20 & 14.98 \\
\hline & Lacks Full Status & 6 & 15.70 \\
\hline \multirow[t]{2}{*}{ Academic \& Social Growth } & Full Status & 20 & 16.14 \\
\hline & Lacks Full Status & 6 & 16.45 \\
\hline \multirow[t]{2}{*}{ Cohesiveness } & Full Status & 20 & 16.23 \\
\hline & Lacks Full Status & 6 & 16.98 \\
\hline \multirow[t]{2}{*}{ School Renewal } & Full Status & 20 & 16.27 \\
\hline & Lacks Full Status & 6 & 16.17 \\
\hline \multirow[t]{2}{*}{ Caring } & Full Status & 20 & 17.33 \\
\hline & Lacks Full Status & 6 & 18.16 \\
\hline \multirow[t]{2}{*}{ Free and Reduced Lunch } & Full Status & 20 & 55.45 \\
\hline & Lacks Full Status & 6 & 71.67 \\
\hline \multirow[t]{2}{*}{ Total Climate } & Full Status & 20 & 131.97 \\
\hline & Lacks Full Status & 6 & 134.86 \\
\hline
\end{tabular}


Table 9

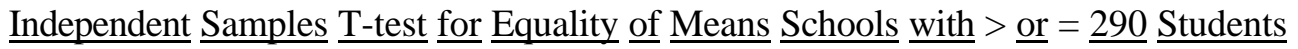

\begin{tabular}{lllll}
\hline Variable & $\underline{\mathrm{t}}$ & $\underline{\mathrm{df}}$ & $\begin{array}{l}\text { Sig. } \\
(2 \text {-tailed })\end{array}$ & $\underline{\mathrm{MD}}$ \\
\hline Free and Reduced Lunch & 2.622 & 24 & $.015^{*}$ & 16.22 \\
\hline * Equal Variance Assumed & & & $\underline{\mathrm{p}}<.05$ &
\end{tabular}

Table 10

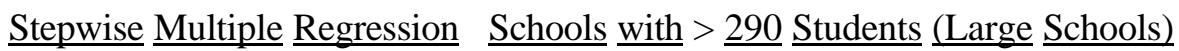

\begin{tabular}{llllll}
\hline Variable & $\underline{\mathrm{B}}$ & $\underline{\mathrm{SE}}$ & Beta & $\underline{\mathrm{t}}$ & Sig. \\
\hline 1 (Constant) & 1.582 & .319 & & 4.957 & .000 \\
Free and Reduced & -1.373 & .005 & -.472 & -2.662 & .015 \\
Lunch & & & & & \\
\hline $\mathrm{p}<.05$ & & & &
\end{tabular}

\section{$\underline{\text { Small Schools }}$}

Thirty-nine of 65 respondent schools (60\%) had an enrollment of less than 290 students and were in this group. As indicated in Table 11, this included 25 of 31 schools (81\%) which lacked full accreditation status and 14 of 34 schools ( 41\%) which earned full accreditation status. Results of an Independent Samples T-test, displayed in Table 12, indicated that a significant difference existed between the mean scores of schools which lacked full accreditation status and those which earned full accreditation status in SES, in total climate, and in the sub categories of respect, trust, high morale, opportunity for input, academic and social growth, cohesiveness, school renewal, and caring. However, results of stepwise multiple regression analysis, as denoted in Table 13, indicated that only cohesiveness and the percentage of students eligible to receive free and reduced lunch were predictors of school accreditation status within this group of small (n 
$<290)$ schools.

Table 11

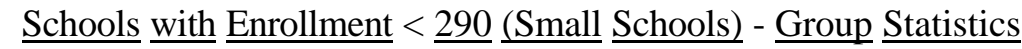

\begin{tabular}{|c|c|c|c|}
\hline Variable & Accreditation Status & $\mathrm{N}$ (schools) & Mean (climate scores) \\
\hline \multirow[t]{2}{*}{ Respect } & Full Status & 14 & 18.52 \\
\hline & Lacks Full Status & 25 & 16.78 \\
\hline \multirow[t]{2}{*}{ Trust } & Full Status & 14 & 17.19 \\
\hline & Lacks Full Status & 25 & 15.07 \\
\hline \multirow[t]{2}{*}{ High Morale } & Full Status & 14 & 17.97 \\
\hline & Lacks Full Status & 25 & 15.11 \\
\hline \multirow[t]{2}{*}{ Opportunity for Input } & Full Status & 14 & 16.57 \\
\hline & Lacks Full Status & 25 & 14.28 \\
\hline \multirow[t]{2}{*}{ Academic \& Social Growth } & Full Status & 14 & 16.88 \\
\hline & Lacks Full Status & 25 & 15.02 \\
\hline \multirow[t]{2}{*}{ Cohesiveness } & Full Status & 14 & 17.79 \\
\hline & Lacks Full Status & 25 & 14.83 \\
\hline \multirow[t]{2}{*}{ School Renewal } & Full Status & 14 & 17.11 \\
\hline & Lacks Full Status & 25 & 15.10 \\
\hline \multirow[t]{2}{*}{ Caring } & Full Status & 14 & 18.38 \\
\hline & Lacks Full Status & 25 & 16.52 \\
\hline \multirow[t]{2}{*}{ Free and Reduced Lunch } & Full Status & 14 & 52.18 \\
\hline & Lacks Full Status & 25 & 80.64 \\
\hline \multirow[t]{2}{*}{ Total Climate } & Full Status & 14 & 140.43 \\
\hline & Lacks Full Status & 25 & 122.73 \\
\hline
\end{tabular}




\section{Table 12}

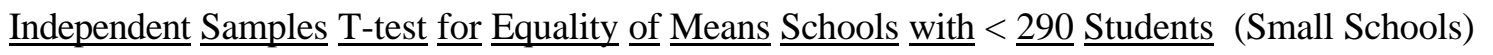

\begin{tabular}{|c|c|c|c|c|}
\hline Variable & $\underline{\mathrm{t}}$ & $\underline{\mathrm{df}}$ & $\begin{array}{l}\text { Sig. } \\
\text { (2-tailed) }\end{array}$ & $\underline{\mathrm{MD}}$ \\
\hline Free and Reduced Lunch & 5.982 & 37 & $.000^{*}$ & 28.50 \\
\hline Respect & -2.992 & 35.995 & .005 & -1.7397 \\
\hline Trust & -3.004 & 37 & $.005^{*}$ & -2.1227 \\
\hline High Morale & -5.218 & 34.906 & .000 & -2.8537 \\
\hline Opportunity for Input & -3.211 & 37 & $.003^{*}$ & -2.2822 \\
\hline Academic \& Social Growth & -2.729 & 37 & $.010^{*}$ & -1.8625 \\
\hline Cohesiveness Mean Response & -4.111 & 37 & $.000 *$ & -2.9597 \\
\hline School Renewal & -2.784 & 37 & $.008 *$ & -2.0099 \\
\hline Caring & -2.973 & 37 & $.005^{*}$ & -1.8691 \\
\hline Total Climate & -3.397 & 37 & $.002 *$ & -17.7010 \\
\hline
\end{tabular}

Table 13

$\underline{\text { Stepwise }} \underline{\text { Multiple }} \underline{\text { Regression }} \underline{\text { Schools }} \underline{\text { with }}<\underline{290} \underline{\text { Students }}$ (Small $\underline{\text { Schools) }}$

\begin{tabular}{llllll}
\hline Variable & $\underline{\mathrm{B}}$ & $\underline{\mathrm{SE}}$ & Beta & $\underline{\mathrm{t}}$ & Sig. \\
\hline 1 (Constant) & 1.574 & .211 & & 7.469 & .000 \\
Free and Reduced Lunch & -1.725 & .003 & -.701 & -5.982 & .000 \\
\hline 2 (constant) & .469 & .529 & & .886 & .381 \\
Free and Reduced Lunch & -1.382 & .003 & -.562 & -4.414 & .000 \\
Cohesiveness & & & & & \\
\hline $\mathrm{p}<.05$ & 5.432 & .024 & .287 & 2.256 & .030 \\
\hline
\end{tabular}




\section{$\underline{\text { Ancillary Findings }}$}

Ancillary findings, as presented in Table 14, were divided into four groups. Groups were (a) small schools with higher SES, (b) large schools with higher SES, (c) large schools with low SES, and (d) small schools with low SES.

Table 14

Ancillary Findings Group Statistics

\begin{tabular}{llr}
\hline Size $<290$ and SES $<66 \%$ (small \& higher SES) & Lacked Full Accreditation & N \\
& Full Accreditation Status & 10 \\
Size $>$ or $=290$ and SES $<66 \%$ (large \& higher SES) & Lacks Full Accreditation & 2 \\
& Full Accreditation Status & 14 \\
Size $>$ or $=290$ and SES $>$ or $=66 \%($ large $\&$ low & Lacks Full Accreditation & 4 \\
SES $)$ & Full Accreditation Status & 5 \\
Size $<290$ and SES $>$ or $=66 \%($ small \& low SES) & Lacks Full Accreditation & 23 \\
& Full Accreditation Status & 4 \\
\hline
\end{tabular}

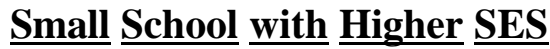

Through analysis using Independent Samples T-test, no significant difference in the mean climate scores was found between schools which lacked full accreditation status and those which earned full accreditation status in small schools with lower rates of free and reduced lunch (size < 290 and SES < 66\%). Twelve of 65 respondent schools (18\%) were in this group. Two schools which lacked full accreditation status (2/31 or .06\%) were in this group, and 10 schools which earned full accreditation status (10/34 or 29\%) were in this group. 


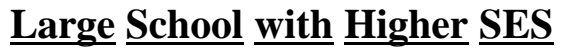

Two schools which lacked full accreditation status (2/31 or .06) were in the second group, large schools with lower rates of free and reduced lunch (size $>$ or $=290$ and SES $<66 \%$ ). Fifteen schools which earned full accreditation status (15/34 or $44 \%)$ were also in this group. Total schools in this group was 17 of the 65 respondent schools (26\%). Through Independent Samples T-test, no significant difference was found between the mean climate scores of schools which lacked full accreditation status and those which earned full accreditation status in this group.

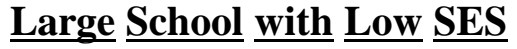

The third group was composed of large schools with high rates of free and reduced lunch $($ size $>$ or $=290$ and SES $>$ or $=66 \%)$. Four schools which lacked full accreditation status $(4 / 31$ or $13 \%)$ and five schools which earned full status (5/34 or $15 \%)$ were in this category. Total schools in this group was 9 of 65 respondent schools (14\%). Again, when the Independent Samples T-test was conducted, no significant difference was found between the mean climate scores of schools which lacked full accreditation status and those which earned full accreditation status.

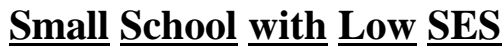

The fourth group, small schools with high rates of free and reduced lunch (size < 290 and SES $>$ or $=66 \%)$, included 23 schools which lacked full accreditation status $(23 / 31$ or $74 \%)$ and four schools which earned full accreditation status (4/34 or 12\%). A total of 27 of the 65 respondent schools (42\%) were in this group. Through the use of Independent Samples T-test, a significant difference between mean climate scores in overall school climate and in six of the eight 
climate subcategories was found to exist between schools which earned full accreditation status and schools which lacked full accreditation status. A significant difference, as displayed in Table 15, was found between accreditation status groups in the subcategories of respect, high morale, opportunity for input, cohesiveness, school renewal, caring, and in total teacher-perceived school climate.

Table 15

$\underline{\text { Independent Samples }} \underline{\text { T-test }} \underline{\text { for Equality }} \underline{\text { of Means }} \underline{\text { Schools }} \underline{\text { with }}<\underline{290} \underline{\text { Students }}$ and SES $\geq \underline{\text { or }}$

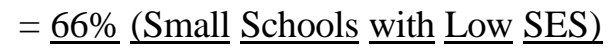

\begin{tabular}{llllr}
\hline Variable & $\underline{\mathrm{t}}$ & $\underline{\mathrm{df}}$ & Sig. (2-tailed) & $\underline{\mathrm{MD}}$ \\
\hline Respect & -3.786 & 24.828 & .001 & -2.1112 \\
High Morale & -5.300 & 24.924 & .000 & 2.7951 \\
Opportunity for Input & -2.691 & 25 & $.013^{*}$ & -3.2086 \\
Cohesiveness & -2.805 & 25 & $.010^{*}$ & -3.5272 \\
School Renewal & -4.403 & 21.275 & .000 & -2.5524 \\
Caring & -2.145 & 25 & $.042^{*}$ & -2.3571 \\
Total Climate & -2.317 & 25 & $.029^{*}$ & -21.1737 \\
\hline *Equal Variance Assumed & & $\mathrm{p}<.05$ &
\end{tabular}

\section{$\underline{\text { Additional Ancillary Findings }}$}

Analysis also indicated that differences in mean scores existed in the climate categories of respect and high morale - as presented in Table 17- and in the percentage of students eligible to receive free or reduced lunch - as presented in Table 18- between schools which lacked full accreditation in both 1997 and 1998 and those which lacked full accreditation status in 1998 only. Through stepwise multiple regression analysis, however, only the school's SES was a predictor of the number of years a school was likely to have lacked full accreditation status. 
Table 16

$\underline{\text { Ancillary Conclusions - Group Statistics }}$

\begin{tabular}{ll}
\hline Lacked Full Accreditation in Both 1997 and 1998 & 23 \\
Lacked Full accreditation Status in 1998 only & 8 \\
\hline
\end{tabular}

Table 17

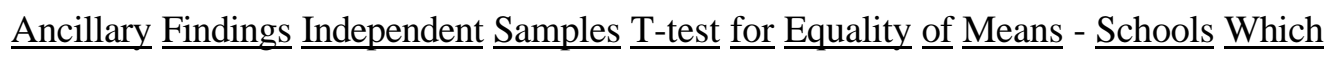

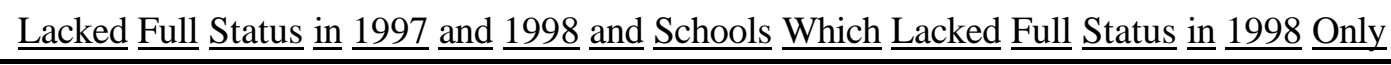

\begin{tabular}{lllll}
\hline Variable & $\underline{\mathrm{t}}$ & $\underline{\mathrm{df}}$ & Sig. (2-tailed) & $\underline{\mathrm{MD}}$ \\
\hline Respect & -2.613 & 26.667 & .015 & -1.4666 \\
High morale & -2.376 & 29 & $.024^{*}$ & -2.0633 \\
SES & 5.505 & 29 & $.000^{*}$ & 17.73 \\
\hline *Equal Variance Assumed & & & $\mathrm{p}<.05$
\end{tabular}

Table 18

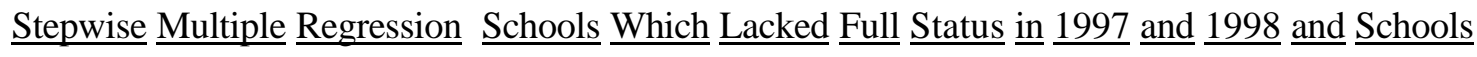

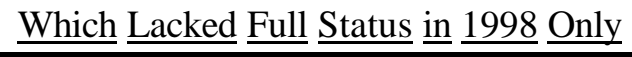

\begin{tabular}{lrrrrr}
\hline Variable & $\underline{\mathrm{B}}$ & $\underline{\mathrm{SE}}$ & Beta & $\underline{\mathrm{t}}$ & sig. \\
\hline 1 (Constant) & -4.141 & 1.530 & & -2.706 & .009 \\
Free and Reduced Lunch & .128 & .021 & .657 & 6.040 & .000 \\
\hline $\mathrm{p}<.05$ & & & & &
\end{tabular}




\section{Summary}

A significant difference existed between mean climate scores in schools which earned full accreditation status and those which lacked full accreditation status. However, when controlled for SES, only high morale was found to be a predictor of accreditation status in low SES schools $(\mathrm{SES} .>$ or $=$ to $66 \%)$. No significant relationship was determined between climate factors and accreditation status in higher SES schools (SES < 66\%).

When controlled for school size, the only predictor of school accreditation status was the percentage of students eligible to receive free and reduced lunch in large schools $(n>$ or $=$ to 290). Large schools with high rates of free and reduced lunch were more likely to lack full accreditation status.

A significant difference existed between the mean climate scores in total school climate, respect, trust, high morale, opportunity for input, academic and social growth, cohesiveness, school renewal, and caring in small schools (size < 290). However, when stepwise multiple regression was conducted, only cohesiveness and the percentage of students eligible to receive free and reduced lunch were identified as predictors of school accreditation status in small schools. High percentages of free and reduced lunch, along with lower mean scores in the area of cohesiveness, indicated a greater possibility that a small school would lack full accreditation status.

Analysis indicated that overall school climate and six of the eight climate sub categories are predictors of school climate in small ( size < 290), low SES (SES > or $=66 \%$ ) elementary schools in West Virginia. The school's SES was determined to be a predictor of the number of years a school had lacked full accreditation status. Schools which lacked full accreditation status 
in both 1997 and 1998 had a much higher percentage of students eligible to receive free and reduced lunch than schools which only lacked full status in 1998. 


\section{CHAPTER FIVE}

\section{Summary, Conclusions, $\underline{\text { Recommendations }}$}

Chapter five provides a general summary of inquiry findings, conclusions supported by data, and recommendations. The following sections are included: (a) summary of purpose and procedures, (b) summary of descriptive data, (c) summary of findings and discussion, (d) conclusions, (e) recommendations, and (f) implications.

\section{$\underline{\text { Summary }} \underline{\text { of Purpose and Procedures }}$}

The purpose of this study was to determine if a statistically significant difference existed between the mean, teacher-perceived school climate in elementary schools which earned full accreditation status and those which lacked full accreditation status within the state of West

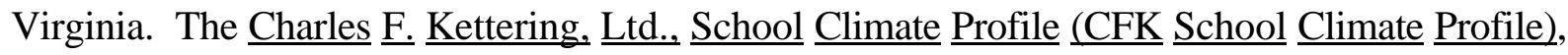
with a validity of .86 and reliability of .96 , was distributed to Faculty Senate Chairpersons in 100 sample schools throughout the state. Faculty Senate Chairpersons were asked to distribute the surveys at the March 1999, Faculty Senate Meeting for teacher completion. Forty-seven schools in the sample were chosen due to their predetermined lack of full accreditation status which was based on student achievement on the 1998, Stanford Achievement Test, Ninth Edition (SAT-9). Fifty-three additional sample schools were randomly selected from the population of 329 elementary schools which earned full accreditation status in both 1997 and 1998.

The overall return rate was $65 \%$, a total of 65 schools. Surveys returned included those from 31 schools which lacked full accreditation status and those from 34 schools which earned full accreditation status. A total of 822 teachers in the 65 schools responded to general climate

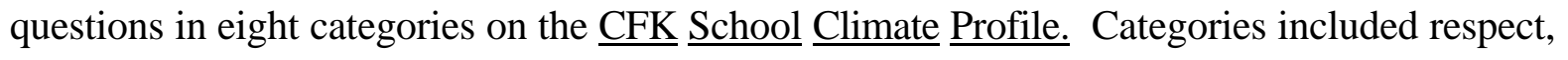


trust, high morale, opportunity for input, continuous academic and social growth, cohesiveness, school renewal, and caring.

\section{$\underline{\text { Summary of Descriptive Data }}$}

The percentage of students eligible to receive United States Department of Agriculture (USDA) free or reduced lunch ranged from $11 \%$ to $99 \%$ in the 65 responding schools. The mean percentage of students who were eligible to receive free or reduced lunch in schools which lacked full accreditation status was $79 \%$. The mean percentage of students who were eligible to receive free or reduced lunch in schools which earned full accreditation status was $54 \%$. The mean percentage of students who were eligible to receive free or reduced lunch in the combined group of 65 responding schools was $66 \%$.

School size, which was based on second month student enrollment, ranged from 68 to 950 students with a mean of 290. Mean student enrollment in schools which lacked full accreditation status was 215. Mean student enrollment in schools which earned full accreditation status was 358.

\section{$\underline{\text { Summary of Findings and Discussion }}$}

Research question number one asked whether or not a statistically significant difference existed between the mean climate scores of schools which earned full accreditation status and those which lacked full accreditation status. Teacher-perceived school climate, with the exception of opportunity for input, was significantly lower in West Virginia elementary schools which lacked full accreditation status than in schools which earned full accreditation status. A statistically significant difference existed in the total mean climate score and in seven of the eight mean climate sub-categories between accreditation status groups when an Independent Samples T-test was 
conducted.

Findings from this study support partial findings by Watts (1997) who identified climate as a predictor of student achievement. Using regression analysis, Watts (1997) determined that, in a sample of 29 Southern West Virginia elementary schools, a statistically significant relationship existed between school climate or health and achievement of sixth graders. Watts employed the Organizational Health Inventory for Elementary Schools (OHI-E) to collect data. Student achievement was measured through the Comprehensive Test of Basic Skills (CTBS).

The Independent Samples T-test conducted in this study, however, included no control for the percentage of students eligible to receive free or reduced lunch or school size. Both SES and school size have been identified in previous studies as having an impact upon student achievement (Finklea, 1997; Howley, 1996; McKee, 1996; Peach, 1996; Schwainger, 1997; Surya, 1994; Watts, 1997).

Research question number two asked whether or not a statistically significant difference existed between the mean climate scores of schools which earned full accreditation status and those which lacked full accreditation status when controlled for the socioeconomic status (SES) of the school. In 36 of the 65 responding schools, at least $66 \%$ of the students were eligible to receive free or reduced lunch. Schools in which greater than or equal to $66 \%$ of the students were eligible to receive free or reduced lunch were considered low SES schools in this study. Within this group of 36 low SES schools, mean climate scores in the sub-categories of respect and high morale were significantly different between accreditation status groups. When stepwise multiple regression analysis was conducted, high morale was a predictor of accreditation status in low SES schools. Twenty-seven of 36 schools in this group lacked full accreditation status, and 
nine of 36 schools earned full accreditation status. In low SES schools, as the mean score in the category of high morale decreased, the likelihood that the school lacked full accreditation status increased. Findings support Gentile's (1997) conclusion that teacher morale was related to student achievement in Pennsylvania middle schools.

In 29 of 65 responding schools the percentage of students eligible to receive free and reduced lunch was less than $66 \%$. Schools in which less than $66 \%$ of the students were eligible to receive free or reduced lunch were considered higher SES schools in this study. Within this group of 29 higher SES schools, no significant differences in mean climate scores were found to exist between accreditation status groups. Four of the 29 schools in this group lacked full accreditation status and 25 earned full accreditation status.

Research question number three asked whether or not a statistically significant difference in the teacher-perceived mean climate scores existed between schools which lacked full accreditation status and those which earned full accreditation status when controlled for school size. In large schools, those which served greater than or equal to 290 students, no significant differences in mean climate scores were found between schools which lacked full accreditation status and those which earned full status. Twenty-six of 65 participating schools were in this group. Six of 26 schools lacked full accreditation status, and 20 of 26 schools earned full accreditation status. The mean percentage of students eligible to receive free or reduced lunch was significantly different between schools which earned full accreditation status and those which lacked full accreditation status in this group. Schools which lacked full accreditation status in this group had a significantly higher percentage of students eligible for free or reduced lunch.

In large, urban schools, McKee (1996) found evidence that African American students 
from low SES backgrounds scored higher in reading and math on fifth grade achievement tests in larger schools. McKee employed separate Analysis of Variance to analyze math and reading scores on the Stanford Achievement Test. McKee divided schools into three groups by size with schools serving less than 655 students defined as small, between 655 and 1055 defined as medium schools, and greater than 1,537 as large schools. In addition, McKee concluded that paid lunch students scored higher on the achievement test than free lunch students.

In 39 small schools, those which served less than 290 students, significant differences between the mean total climate score and mean scores in all eight sub-categories were found to exist between accreditation status groups. Included in this group were 25 schools which lacked full accreditation status and 14 schools which earned full accreditation status. When stepwise multiple regression analysis was conducted, however, only the climate factor cohesiveness and the percentage of students eligible to receive free and reduced lunch were predictors of accreditation status in small $(\mathrm{n}<290)$ schools. As the percentage of students who were eligible to receive free and reduced lunch increased and the mean score in the area of cohesiveness decreased, the likelihood that the school earned full accreditation status decreased.

Ancillary findings were used to divide the 65 respondent schools into four groups when combining schools by size and SES. Schools with enrollment greater than or equal to 290 and less than $66 \%$ of the school's students eligible to receive free or reduced lunch were identified as large schools with higher SES. Schools with enrollment greater than or equal to 290 and greater than or equal to $66 \%$ of the school's students eligible to receive free or reduced lunch were identified as large schools with low SES. Schools with enrollment less than 290 and less than $66 \%$ of the school's students eligible to receive free or reduced lunch were identified as small schools 
with higher SES. Schools with enrollment less than 290 and greater than or equal to $66 \%$ of the school's students eligible to receive free or reduced lunch were identified as small schools with low SES. No significant differences in mean climate scores were found to exist between school accreditation status groups in large, higher SES schools; in large, low SES schools; or in small, higher SES schools.

Twenty-seven of the 65 responding schools served fewer than 290 students, and at least $66 \%$ of each school's students were eligible to receive free or reduced lunch. This group of 27 small, low SES schools included 23 schools which lacked full accreditation status and four schools which earned full accreditation status. In small, low SES schools, significant differences in the mean scores of the climate sub-categories respect, high morale, opportunity for input, cohesiveness, school renewal, and caring were found to exist between the two accreditation status groups.

Findings from this study are consistent with those reported by Arnold (1996) and Stevenson (1996). Arnold's (1996) results indicated that students in small, poor rural Michigan schools achieved at lower levels than students in other types of schools. Small school districts with small rural schools often have higher operating costs because of the inability to meet the economies of scale. Arnold analyzed data on human resources and student achievement for a ten year period from 1983-84 through 1993-94. Stevenson (1996) found that larger schools received more recognition for their student achievement from state and national organizations than did smaller schools.

Findings from the current analysis may appear to contradict the outcome of Howley's 1996 West Virginia inquiry. Howley concluded that impoverished children benefitted from small 
rural schools and that only affluent children benefitted from large schools. However, Howley measured individual student achievement through the Comprehensive Test of Basic Skills (CTBS). The current analysis measured only school accreditation status as reported by the West Virginia Performance Based Accreditation System which was based on total school achievement. Howley's definition of school size was also different than the definition of school size used in this study. Howley used the cohort group method of defining school size. For example, if a third grade cohort was composed of 50 students, then Howley defined each class in the school as serving 50 students. According to Howley, who used previous West Virginia Board of Education Policy, a small cohort or class would serve fewer than 50 students. A kindergarten through sixth grade school with 50 students in the cohort group would be defined as a school of 350 students. By definition, a school with less than 350 students would be described as small according to Howley, as compared to a school with less than 290 students being defined as small in this study. Howley employed regression analysis in his state-wide study of West Virginia elementary schools.

Twenty-three of the 65 schools that participated in this study lacked full accreditation status in both 1997 and 1998. Eight of the 65 schools lacked full accreditation status in 1998 only. The percentage of students eligible to receive free or reduced lunch in schools which lacked full accreditation status both years was $83 \%$. In schools which lacked full accreditation status for only one year, the percentage of students eligible to receive free or reduced lunch was $66 \%$. Through analyses utilizing both the Independent Samples T-test and multiple regression, statistical significance was indicated. Significant differences in the mean percentage of students eligible to receive free or reduced lunch, as well as the mean scores of climate factors respect and high morale, existed between the two accreditation status groups. The higher the percentage of 
students eligible to receive free or reduced lunch, the more likely it was that the school lacked full accreditation status.

SES continuously emerged as a factor related to school accreditation status in this study. This finding supports findings by Finklea, 1996; Peach , 1996; Schwainger, 1997; Surya, 1994; and Watts, 1997. Surya determined that student achievement was lower in low SES groups of Pennsylvania elementary schools as compared to high SES groups of schools. Surya's study included 30,260 teachers in 1,248 elementary schools throughout the state of Pennsylvania. The level of SES was divided into three groups. Stepwise multiple regression was used in each group to examine the relative contribution of independent variables to student achievement on The Essential Learning and Literacy Skills (TELLS).

Schwainger (1997) identified group differences for high and low SES students on academic achievement, measured through the Iowa Test of Basic Skills in a small $(\mathrm{n}<90)$ midwestern, year round urban school which served students in grades kindergarten through third grade. Students from backgrounds of low SES showed lower achievement. One-way Analysis of Variance was employed.

In secondary schools in South Carolina, Finklea (1997) found that a highly negative correlation existed between SES and school effectiveness. Linear models were employed with $\mathrm{p}<.05$. In addition to climate factors associated with sixth grade student achievement on the Comprehensive Test of Basic Skills (CTBS), Watts (1997) found a strong relationship between SES and student achievement. Regression Analysis was used with $\mathrm{p}<.05$.

In ten suburban elementary schools in Kansas City, Missouri, Peach’s (1996) sample included matched cohort pairs to conclude that a consistent difference between mean achievement 
test scores existed between low SES students and high SES students. Peach utilized dependent t-tests in the analysis of data.

\section{Conclusions}

Conclusions were based on findings from this study and supported by findings from studies previously discussed. Conclusions are as follows:

1. High morale is related to student achievement, and therefore high morale is related to state accreditation status of elementary schools in West Virginia. Two possible phenomena exist to explain this finding. a) High morale may be lower in schools which lack full accreditation due to the actual lack of accreditation itself, which is often viewed as difficult to achieve in low SES schools. b) Lower morale may lead to a school's lack of full accreditation status.

2. Stevenson and Pellicer's (1998) findings indicate that small schools offer a more caring, family-like atmosphere. In this study, however, cohesiveness was found to be lower in small respondent schools which lacked full accreditation status. A sense of cohesiveness among teachers, administrators, and students may promote a team spirit which encourages and promotes individuals to work together toward common goals. Individuals working together toward common goals may lead to higher student achievement. Higher student achievement may increase a school's chance of earning full accreditation status.

3. SES is related to student achievement and therefore to state accreditation status of elementary schools in West Virginia. Statistically, $50 \%$ of the students who take a normreferenced test such as the SAT- 9 must score below the $50^{\text {th }}$ percentile and $50 \%$ must 
score above the $50^{\text {th }}$ percentile. If more than $50 \%$ of the test-takers score above the $50^{\text {th }}$ percentile then scores equivalent to the $50^{\text {th }}$ percentile rise, and students will have to score higher to be within the upper two quartiles. Based on findings from this study and supported by findings of studies previously discussed, it is likely that low SES schools will be the schools with the highest number of students scoring below the 50th percentile and will therefore lack full accreditation status.

4. In higher SES schools students may be members of families in which parents have better paying jobs and therefore perhaps more education. Parents with greater education may understand the educational process better and may place more emphasis upon the process of education. Also, students from higher SES backgrounds may have broader life experiences and may be better able to relate to items on sometimes culturally biased achievement tests.

\section{$\underline{\text { Recommendations }}$}

Findings provide the basis for the following recommendations:

1. It is recommended that this study be replicated in five years, using the same sample, to determine if teacher perception of school climate has changed and if accreditation status has changed.

2. It is recommended that this study be replicated utilizing a different climate instrument. 3. It is recommended that this study be replicated in West Virginia schools of other grade level configurations.

4. It is recommended that this study be replicated in other states which use student achievement test results to grant accreditation status. 
5. It is recommended that replication occur using data collected through this inquiry in addition to interviews conducted in a qualitative manner in order to gain additional knowledge concerning the school climate and accreditation status.

6. It is recommended that this study be replicated to include a new variable, lack of accreditation status due to greater than $15 \%$ of students scoring in the bottom quartile on the Stanford Achievement Test, which emerged with spring 1999, student testing.

7. It is recommended that a study be conducted to determine if decreased morale leads to decreased chances of accreditation status or if decreased morale is a result of a current lack of full accreditation status in small, low SES schools.

8. It is recommended that this study be repeated so that SES is divided into three groups rather than two groups using the mean as the dividing point.

9. It is recommended that this study be repeated with school size being divided into three groups rather than two groups using the mean as the dividing point.

\section{Implications}

Results of this study imply that climate, SES, and school size appear to be related to accreditation status, which is granted to public schools in West Virginia based primarily on student achievement. SES consistently emerged as a factor relating to school accreditation status in this investigation. Even though the socioeconomic background of students cannot be changed, both school climate and school size can be changed.

To improve an elementary school's overall potential for earning full accreditation status, leaders in West Virginia elementary schools should attempt to improve the total school climate and school climate in the areas of respect, trust, high morale, cohesiveness, academic and social 
growth, school renewal, and caring. Leaders in low SES schools should place a great emphasis on improving morale to improve accreditation status. In small, low SES schools, leaders should place great emphasis on building cohesiveness in order to improve the school's chances of earning full accreditation status.

County boards of education may use this information in their efforts to consolidate schools and in the process of redistricting attendance areas. Both consolidation and redistricting may expand boundaries to include students from a broad range of socioeconomic backgrounds as well as to increase enrollment. While this does not necessarily increase individual student achievement, it does increase the likelihood that a school will earn full accreditation status. The West Virginia School Building Authority may use results of this study in the decision-making process when awarding consolidation funds to county school systems.

School administrators may use findings from this inquiry in planning activities to improve school climate; especially activities which emphasize building cohesiveness and high morale. Superintendents, school management teams, and curriculum administrators may use findings to emphasize the need for small, low SES schools to build a cohesive atmosphere and improve high morale. Directors of Staff Development may use the results in planning professional development activities for administrators and teachers which include activities to improve school climate and build cohesiveness during the staff development sessions.

Conclusions resulting from this inquiry include very important information for principals in small, low SES schools lacking full accreditation status. Principals in small, low SES schools may gain a greater understanding of the need to improve school climate in order to improve their chances of earning full state accreditation status. Professors in colleges and universities may use 
the information in planning curriculum to address the need for a positive school climate which includes high degrees of respect, trust, high morale, opportunity for input, school renewal, continuous academic and social growth, cohesiveness, and caring.

Often educators argue that children of low SES backgrounds bring "too much baggage" to school, and this limits their performance on, perhaps culturally biased, achievement tests (Rogers, 1999). For students who do come from backgrounds of low SES, education may well be their main opportunity to eventually change their socioeconomic status in life. Rather than lowering standards for students attending low SES schools, perhaps consolidating small schools into larger schools to include a broader background of SES, or redistricting school attendance areas to increase enrollment and include a broader background of SES, might be more beneficial to both the school the students. Although this study does not indicate that larger schools benefit individual children, if a school is more likely to earn full accreditation status, then teachers may have more time to emphasize teaching and learning rather than preparing children to take a standardized test.

On the other hand, because the results of numerous research studies strongly indicate that SES is a factor definitely related to achievement when measured through standardized achievement tests, perhaps other criteria for assessing school effectiveness and accreditation should be implemented without lowering standards. While it is important to keep standards high for all children, one must question the validity of using one norm-referenced test to measure student achievement in determining a school's full accreditation status.

Finally, knowing the limitations that SES impose on student achievement measured through standardized tests, the West Virginia state Legislature may wish to study other means of 
granting accreditation to schools. Other means of granting accreditation should continue to stress the importance of high standards for all but include a more diverse means of assessment. 


\section{REFERENCES}

Almond, S. B. (1993). A Comparison of School Practices Exhibited by Principals of Effective and Less Effective Elementary Schools in Alabama. Dissertation Abstracts International, 54-04A, 1157. Abstract from: First Search File: Dissertation Abstracts Online

Al-Gasim, S. S. (1991). The Relationship Between Principal Leader behavior and Middle School Climate in Hail District, Saudi Arabia. Dissertation Abstracts International, 53-01A, 0025. Abstract from: First Search File: Dissertation Abstracts Online

Anderson, C. (1982). The Search for School Climate: a review of the research. Review of Educational Research, 52(3), 368-420.

Arnold, M. (1996). An Equity Analysis of Michigan's School Finance System for Students in Small Rural School Districts. Dissertation Abstracts International, 57-11A, 4655. Abstract from: First Search File: Dissertation Abstracts Online

Ausejo, L. (1983). The Relationship Between the Elementary Principals Leader Behavior and the Urban School Climate in the California Education System. Dissertation Abstracts International, 45-01A, 0026. Abstract from: First Search File: Dissertation Abstracts Online

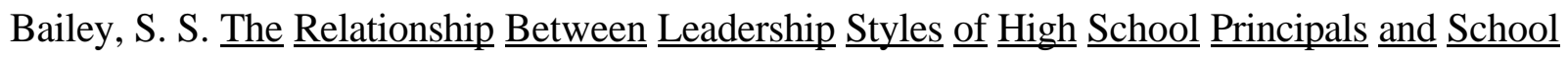

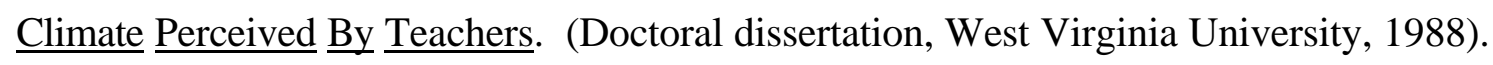
Bloom, P. W. (1990). A Comparison of Principal and Staff Perceptions of School Climate in Effective Schools. Dissertation Abstracts International, 51-06A, 1839. Abstract from: First Search File: Dissertation Abstracts Online 
Chrispeels, J. A, (1990). A Study of Factors Contributing to Achieving and Sustaining School Effectiveness in Elementary Schools. Dissertation Abstracts International, 51-07A, 2209. Abstract from: First Search File: Dissertation Abstracts Online

Clarke, M. (1997). The Interaction of Family Structure, Socioeconomic Status, School Vacations, and Student Achievement of High School Students. Dissertation Abstracts International, 58-06A, 2405 . Abstract from: First Search File: Dissertation Abstracts Online

Coleman, J. S., et. al. (1966). Equality of educational opportunity.

Washington, D. C. : U. S. Office of Education, National Center for Educational Statistics. Cordero, L. R. (1996). Relationships Between Teacher Perceptions of Effective School Characteristics and Academic Achievement of Limited English Proficient Students in New York City. Dissertation Abstracts International, 57-06A, 2287. Abstract from: First Search File: Dissertation Abstracts Online Debella, E. R. (1984). An Analysis of Elementary Yeshiva School Principals' and Faculties’ Perceived Leadership Behavior and Organizational Climate in New Jersey and the New York City Boroughs of Brooklyn, Manhattan, and Staten Island. Dissertation $\underline{\text { Abstracts }}$ International, 45-11A, 3248. Abstract from: First Search File: Dissertation Abstracts Online

DeMoulin, D. F. (1993). Perceived Efficacy of Elementary, Middle, and Secondary School Principals. National Forum of Educational Administration and Supervision Journal $\underline{10} \underline{\underline{(2)}}$, 30-36.

Dennis, P. J. (1979). An assessment of the construct validity and reliability of the CFK Ltd., 


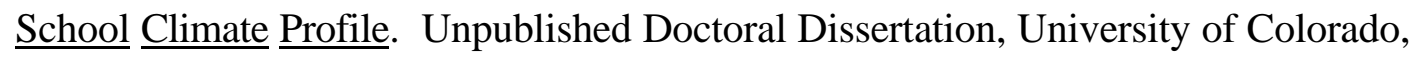
Colorado.

Depasquale, F. J. (1996). Principal Leadership Behavior and Faculty Trust: Is there a

Connection? Dissertation Abstracts International, 57-04A, 1409. Abstract from: First

Search File: Dissertation Abstracts Online

Dickson, E. L. (1991). The Relationship Between Teacher-Preferred and Teacher-Perceived

Leadership Style of the Principal, and the Effect of the Relationship Upon School Climate.

Dissertation Abstracts International, 53-03A, 0672. Abstract from: First Search File:

Dissertation Abstracts Online

Drake, L. A. (1997). Perceptions of School Leadership and Its Effect on Climate In A Suburban

School System. Dissertation Abstracts International, 58-08A, 2921. Abstract from: First

Search File: Dissertation Abstracts Online

Earthman, G. I., and LeMasters, L. (1996). Review of Research on the Relationship Between

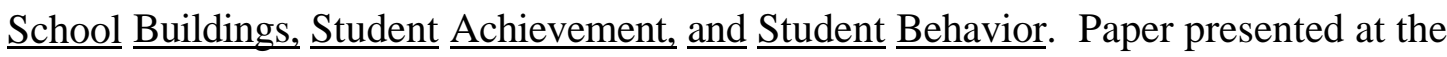
annual meeting of the Council of Educational Facilities Planners, International (Tarpon Springs, Florida, October 8, 1996).

Edmonds, R. (1978, July). A Discussion of the literature and issues related to effective schooling. Paper presented at the National Conference of Urban Education, St. Louis, Missouri.

Edmonds, R. (1979, October). Effective school for the urban poor. Educational Leadership, $\underline{37}$ (2), pp.15-27.

Edmonds, R. , \& Fredericksen, N. (1978). Search for effective schools: The identification and

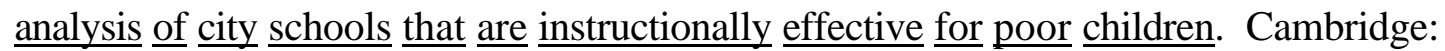


Harvard University, Center for Urban Studies.

Edwards, B. (1994). Leadership Style and Organizational Climate in Rural Saskatchewan.

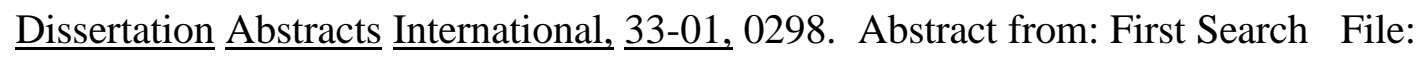
Dissertation Abstracts Online

Epstein, J. L., and McPartland, J. M. (1978). The concept and measurement of the quality of school life. American Educational Research Journal, 13, 15-30. and organizational performance. New York: John Wiley.

Finklea, C. W. (1997). Principal Leadership Style and the Effective School. Dissertation

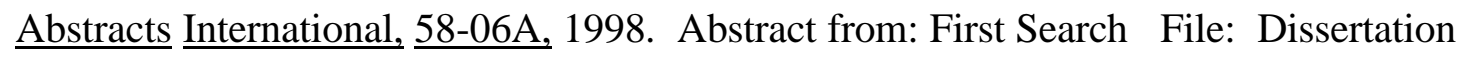
Abstracts Online

Fite, E. C. (1995). A Study of the Impact of Outcomes Accreditation on Classroom Instruction, Student performance, and School Climate in One Inner-City Secondary School.

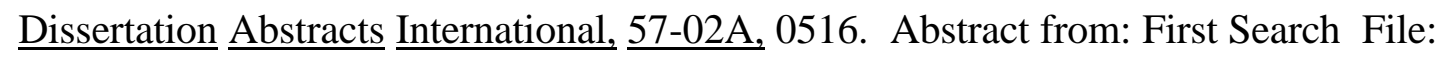
Dissertation Abstracts Online

Fleishman, E. A. (1973). Twenty years of consideration and structure. In E. A.

Fox, R. S., et al. (1973). School Climate Improvement: $\underline{A}$ challenge to school administrators. Bloomington, Indiana: Phi Delta Kappa, Inc.

Gaines, M. C. (1997). The Effects of Administrative Teams on School Climate. Dissertation

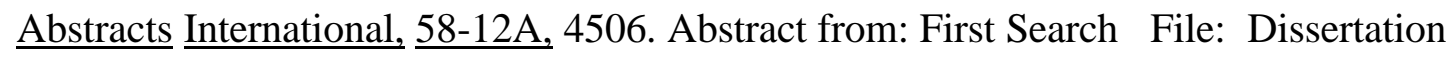
Abstracts Online

Gentile, M. A. (1997). The Relationship Between Middle School Teachers' Perceptions of School Climate and Reading and Mathematics Achievement. Dissertation Abstracts 
International, 58-12A, 4600. Abstract from: First Search File: Dissertation Abstracts Online

Gulick, L. \& Urwick, L., Eds. (1937). Papers on the Science of Administration. New York: Columbia University Press.

Halpin, A. W. (1957). Manual for the Leader Behavior Description Questionnaire. Columbus, Ohio: Ohio State University.

Halpin, A. W. , \& Croft, D.B. (1962, August). The Organizational Climate of $\underline{\text { Schools. }}$

Washington, D. C. : U. S. Office of Education, Research Project, Contract SAE 543-8639.

Hansen, S. M. (1992). The Relationship Between Faculty Readiness to Change ans Faculty Perception of Elementary School Principals' Leadership Behavior. Dissertation Abstracts International, 53-04A, 1003. Abstract from: First Search File: Dissertation Abstracts Online

Houseknecht, S. E. (1990). The Relationship Between the Perceived Leadership Behaviors and the Morale of Elementary Classroom Teachers. Dissertation Abstracts International, $\underline{51-}$ 10A, 3287. Abstract from: First Search File: Dissertation Abstracts Online

Hoy, W. and Miskel, C. (1982). Educational Administration: theory, research, and practice $\left(2^{\text {nd }}\right.$ ed.). New York: Random House.

Hoy, W., and Hannum, J. W. (1997). Middle School Climate: An Empirical Assessment of Organizational Health and Student Achievement. Educational Administration Quarterly, $\underline{\text { 33- }}$ $\underline{3}, 290-311$.

Howard, E. (1981). School climate improvement: rationale and process. $\underline{\text { Illinois }} \underline{\text { School }} \underline{\text { Research }}$ and Development, pp. 17-20. 
Howard, E., Howell, B., \& Brainard, E. (1987). Handbook for Conducting $\underline{\text { School Climate }}$ Improvement Projects. Bloomington, Indiana: PDK Education Foundation.

Howley, C. (1989). Synthesis of the effects of school and district size: What research says about

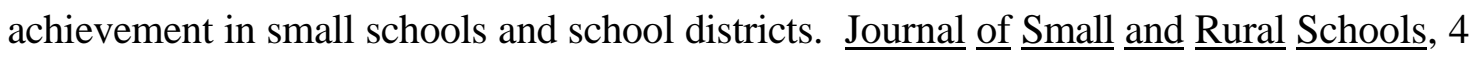
(1), 2-12.

Howley, C. $\underline{\text { Sizing }} \underline{\mathrm{Up}} \underline{\text { Schooling: }} \underline{\mathrm{A}} \underline{\text { West }} \underline{\underline{\text { Virginia }}} \underline{\text { Analysis }} \underline{\text { and }} \underline{\underline{\text { Critique. }}}$ (Doctoral dissertation, West Virginia University, 1996).

Jackson, B. G. (1997). Leader Behaviors, School Climate, School Size and Out-Of-School Suspensions In Selected Public Senior High Schools. Dissertation Abstracts International, 58-08A, 2928. Abstract from: First Search File: Dissertation Abstracts Online

Johnson, M. C. (1991). The Relationship Of Teachers' Perceptions of Leader Behaviors and Their Perceptions of Climate. Dissertation Abstracts International, 52-07A, 2347. Abstract from: First Search File: Dissertation Abstracts Online Jones, L. F., (1996). School Social Climate and Individual Student Achievement in Rural High Schools. Dissertation Abstracts International, 57-07A, 2769. Abstract from: First Search File: Dissertation Abstracts Online

Kelley, E. A. (1980). Improving school climate: Leadership techniques for principals. Reston, Virginia: The National Association of Secondary School principals.

Kerlinger, F. N. (1986). Foundations of Behavioral Research, Third Edition. Fort Worth: Harcourt Brace Jovanovich College Publishers.

Kirkpatrick, S. A. , \& Locke, E. A. (1991). Leadership: Do Traits Matter? The Executive, 5, 4860. 
Knab, D. K. (1998). Comparison of the Leadership Practices of Principals of Blue Ribbon Schools With Principals of Randomly Selected Schools. Dissertation Abstracts International, 59-03A, 0677. Abstract from: First Search File: Dissertation Abstracts Online

Lamdin, D. J. (1995). Testing for the effect of school size on student achievement within a school district. Education Economics, 3 (1), 33-41.

LeMasters, L. K. (1997). A Synthesis of Studies Pertaining to Facilities, Student Achievement, and Student Behavior. Dissertation Abstracts International, 58-02A, 0354. Abstract from:

First Search File: Dissertation Abstracts Online

Likert, R. (1961). New patterns of management. New York: McGraw-Hill.

Lowe, T. J. (1995). The Relationship Of Teacher Attitudes Toward Evaluation and School Building Climate. Dissertation Abstracts International, 56-05A, 1658. Abstract from: First Search File: Dissertation Abstracts Online

Maiden, J, and Foreman, B. A. (1998). Cost, Design, and Climate: Building a Learning Environment. School Business Affairs, $\underline{64-1}$, 40-44.

Mann, R. D. (1959). A review of the relationship between personality and performance in small groups. Psychological Bulletin, 56, 241-270.

Marockie, H. (1997). West Virginia Performance Based $\underline{\text { Accreditation }} \underline{\text { System }} \underline{\text { School District }}$ $\underline{\text { Approval }} \underline{\text { Status }} \underline{\text { and }} \underline{\text { School Accreditation }} \underline{\text { Status. }}$. West Virginia Department of Education. Marockie, H. (1997, 1998). West Virginia Performance $\underline{\text { Based Accreditation }} \underline{\text { System }} \underline{\text { School }}$ $\underline{\text { District }} \underline{\text { Approval }} \underline{\text { Status }} \underline{\text { and }} \underline{\text { School Accreditation }} \underline{\text { Status. }}$. West Virginia Department of Education. 
Marockie, H. (1997, 1998). West Virginia Education Directory. West Virginia Department of Education.

McGuffey, C. W. (1991). Large school/small school issue in Georgia schools. CEFPI's Educational Facility Planner, 29 (6), 17-24.

McDonald-Risik, C. A. (1997). The Leadership Characteristics of Elementary Principals in Recognized Exemplary Schools in a Large Suburban School District in North Central Texas: Six Case Studies. Dissertation Abstracts International, 58-10A, 3789. Abstract from: First Search File: Dissertation Abstracts Online

McKee, G. T. (1996). The Relationship of Elementary School Size to the 1996 Stanford Achievement Test Scores of Fifth-Grade Students. Dissertation Abstracts International, 57-12A, 5126. Abstract from: First Search File: Dissertation Abstracts Online Murray, H.A., (1938). Exploration in Personality. New York: Oxford University Press. Onyeri, I. N. (1988). An Analytical Study of the Relationship Between Leadership Styles of Principals and Organizational Climate Within Selected Elementary Schools. Dissertation

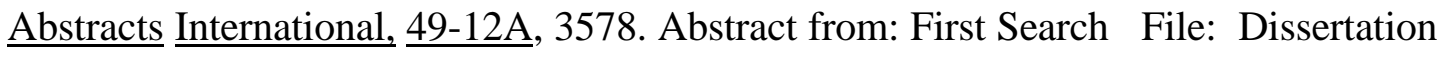
Abstracts Online

Peach, K. (1996). The Effects of Socioeconomic Status on Student Achievement: A Longitudinal Study. Dissertation Abstracts International, 58-01A, 0050. Abstract from: First Search File: Dissertation Abstracts Online

Rasmussen, B. K. (1995). Perceptions of School Climate, Job Satisfaction, Stress, and Burnout, and Their Relationship to Teacher absenteeism. Dissertation Abstracts International, $\underline{56-}$ 09A, 3402. Abstract from: First Search File: Dissertation Abstracts Online 
Robinson, C. T. (1996). School Effectiveness Behaviors of Elementary School Principals in Mississippi. Dissertation Abstracts International, 58-01A, 0152. Abstract from: First Search File: Dissertation Abstracts Online

Rogers, J. (1999, May 22). Testing and evaluation. The Charleston Gazette, pp. A1, A3.

Rutter, M. et. al. (1979). Fifteen thousand hours. Cambridge: Harvard University Press.

Salas, K. M. (1992). School Leadership: Communicating Organizational Vision and School

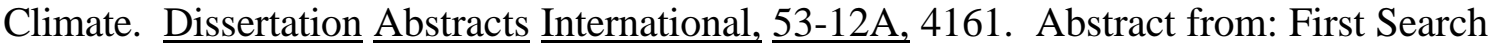

File: Dissertation Abstracts Online

Sackney, L. (1988). Enhancing School Learning Climate: Theory, Research, and Practice.

Saskatoon, Saskatchewan: University of Saskatchewan, S.S.T.A. Research Centre Report No. 180.

Schwaninger, M. (1997). A Case Study of a Year-Round School in the Midwest in an Urban

Setting. Dissertation Abstracts International, 58-08A, 3012. Abstract from: First Search

File: Dissertation Abstracts Online

Sellers, P. L. (1984). A Comparative Study of School Climate and the Leadership Style of

School Principals. Dissertation Abstracts International, 45-10A, 3043. Abstract from: First

Search File: Dissertation Abstracts Online

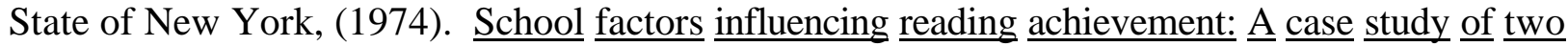
inner city schools. New York: Office of Education Performance Review.

Stevenson, K. R., (1996). Elementary school student capacity: What size is the right size? CEFP Journal, 33 (4), 10-14.

Stevenson, K. R., and Pellicer, L. O. (1998) Is Bigger Really Better? School Business $\underline{\text { Affairs, }}$ 


\section{4-1, 18-23.}

Stockton, C. E. (1997). A Study of Identified Principals’ Leadership Style, School Climate and Parental Involvement, as Perceived by Teachers and Parents, in Selected School Districts in

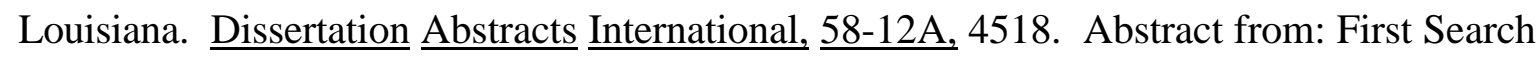
File: Dissertation Abstracts Online

Stroud, Y. P. (1993). Rural Pattern of Excellence: A Case Study of Clay County Junior High School. Dissertation Abstracts International, 54-06A, 2044. Abstract from: First Search File: Dissertation Abstracts Online

Stueven, G. L. (1985). Elementary School Principal Leadership Style: Its Relatinship to School Climate. Dissertation Abstracts International, 46-06A, 1476. Abstract from: First Search File: Dissertation Abstracts Online

Summers, E. (1992). A Study of the Simultaneous Impact of Mobility and Socioeconomic Status on Student Achievement. Dissertation Abstracts International, 53-07A, 2241. Abstract from: First Search File: Dissertation Abstracts Online

Surya, D. (1994). Factors that Influence Student Achievement in Pennsylvania Public Schools. Dissertation Abstracts International, 55-07A, 1757. Abstract from: First Search File: Dissertation Abstracts Online

Tagiuri, R. (1968). The Concept of Organizational Climate. In R. Tagiuri \& G. H. Litrevin (Eds.), Organizational climate: Explanation of a concept. Boston: Harvard University Press. Tom, S. L. (1995). The Relationship of Learning Climate on Student Achievement in the San

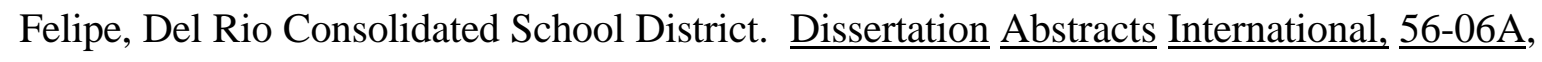
2073. Abstract from: First Search File: Dissertation Abstracts Online 
Traufler, V. J. (1992). The Relationship Between Student Achievement and Individual Correlates of Effective Schools in Selected Schools of South Carolina. Dissertation Abstracts

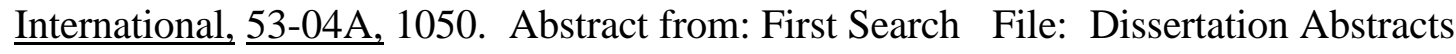
Online

Vandett, W. J., (1998). Developing an indicator system for elementary schools: A case study.

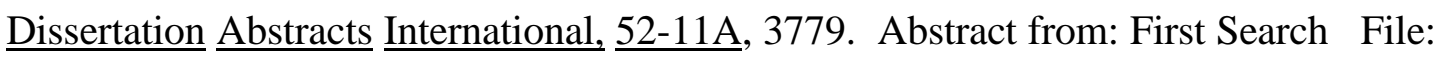
Dissertation Abstracts Online

Villani, C. J. (1996). The Interaction of Leadership and Climate in four Suburban Schools: Limits and Possibilities. Dissertation Abstracts International, 59-01A, 0048. Abstract from: First Search File: Dissertation Abstracts Online

Voelkl, K. E. (1995). School warmth, student participation, and achievement. The Journal of Experimental Education, 63, 127-38.

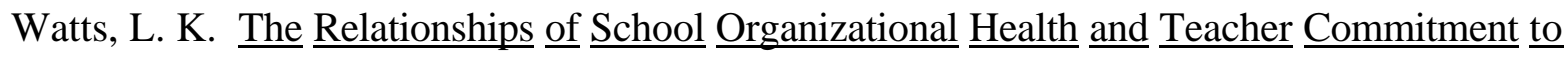
$\underline{\text { Student }} \underline{\text { Achievement }} \underline{\text { in Selected }} \underline{\text { West }} \underline{\text { Virginia Elementary }} \underline{\text { Schools. }}$ (Doctoral dissertation, West Virginia University, 1997).

Weber, G. (1971). Inner-city children can be taught to read: $\underline{\text { Four successful schools. }}$ Washington, D. C. : Council for Basic Education.

$\underline{\text { West Virginia School Code, }}$ (1997, edition). Charlottesville, Virginia: Michie.

West Virginia Department of Education (1999). Guidelines \& Procedures of the School Building Authority. State Board of Education Policy $\underline{6200 .}$

Williams, S. W. (1980). The Relationship Between Leader Behavior of the Principal and school climate. Dissertation Abstracts International, 41-10A, 4249. Abstract from: First Search 
File: Dissertation Abstracts Online

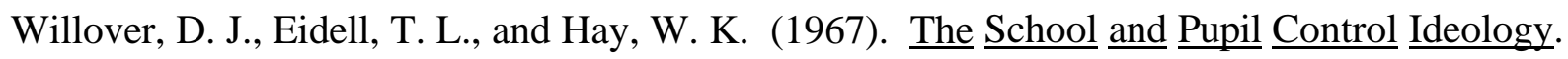
University Park: Pennsylvania State University.

Withrow, J. W. (1993). An Investigation of the Influence on the Relationship Between Principal Leadership Style, School Climate, and School and Teacher Variables in Secondary Schools of Halifax County-Bedford District School Board, Nova Scotia, Canada. Dissertation

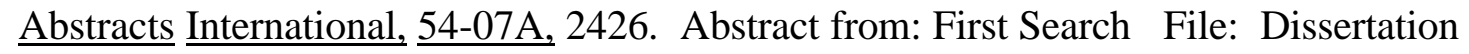
Abstracts Online

Woods, K. A. (1998). Leadership Factors That Influence Educational Excellence. Dissertation Abstracts International, 59-03A, 0688. Abstract from: First Search File: Dissertation Abstracts Online

Zakariya, S. B. (1983). Effective Instructional Management. Arlington, Virginia: American Association of School Administrators.

Zielke, W. E. (1989). The Relationship Among Principals' Leadership Behavior, The Instructional Leadership Climate, and Pupil Control Behavior. Dissertation Abstracts International, 51-02A, 0378. Abstract from: First Search File: Dissertation Abstracts Online 
Appendix A

Mailing Request 
Dear Faculty Senate Chairperson:

As a leader in your school, your help is greatly needed. You are being asked to participate in a state-wide study that will attempt to determine if a significant relationship exists between school accreditation status of West Virginia elementary schools and school climate, school size, and the socioeconomic status of students. School accreditation status is measured by Stanford Achievement Test Data, state-onsite reviews by an accreditation team, and student attendance rates. School climate will be measured by a mean score on the $\underline{\text { Charles }} \underline{\text { F. Kettering }} \underline{\text { School }}$

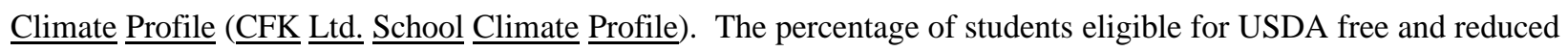
lunch in the selected sample schools and school size have been provided by the West Virginia Department of Education, Office of Child Nutrition.

You are being asked to take approximately ten minutes of your March 1999 Faculty Senate meeting, or other convenient time, to complete the enclosed one page survey. There are enough copies enclosed for all members of your teaching faculty. Participation is voluntary and you are under no obligation to answer every question. Your responses will remain anonymous. Neither you nor your school will be identified by name in any subsequent reports.

If you choose to participate, please collect participating teacher response forms in the enclosed return envelope and mail them as soon as possible. I am conducting this research as part of my Doctoral program in Education Administration. I will be happy to answer any questions you may have concerning this study. You may contact me during the school day at (304) 348-6155.

As an educator in the public school system in West Virginia, I am aware of the many pressing issues you are required to cover at your Faculty Senate meeting. I greatly appreciate your cooperation in taking the time to complete the enclosed survey.

Sincerely,

Elaine D. Gayton, Doctoral Candidate

Enclosures 
Appendix B

Survey 


\section{The CFK LTD. School Climate Profile}

Directions: This instrument provides you the opportunity to express your feelings about many aspects of your school's climate. Although it may not include every item you consider important in your school, it does provide an overall assessment of a school's climate. Read each item thoughtfully and indicate a rating for each by circling the appropriate number using the following scale:

\section{1 - Almost Never 2 - Occasionally 3 - Frequently 4 - Almost Always}

RESPECT:

1. In this school even low achieving students are respected.

2. Teachers treat students as persons.

3. Parents are considered by this school as important collaborators.

4. Teachers from one subject area or grade level respect those from other subject areas.

5. Teachers in this school are proud to be teachers.

$\begin{array}{llll}1 & 2 & 3 & 4 \\ 1 & 2 & 3 & 4 \\ 1 & 2 & 3 & 4 \\ 1 & 2 & 3 & 4 \\ 1 & 2 & 3 & 4\end{array}$

\section{TRUST:}

1. Students feel that teachers are "on their side."

2. While we don't always agree, we can share our concerns with each other openly.

3. Our principal is a good spokesperson for our interests and needs before the superintendent and board.

4. Students can count on teachers to listen to their side of the story and to be fair.

5. Teachers trust students to use good judgement.

$\begin{array}{llll}1 & 2 & 3 & 4 \\ 1 & 2 & 3 & 4 \\ 1 & 2 & 3 & 4 \\ 1 & 2 & 3 & 4 \\ 1 & 2 & 3 & 4\end{array}$

HIGH MORALE:

1. This school makes students enthusiastic about learning.

2. Teachers feel pride in this school and in its students.

3. Attendance is good; students stay away only for urgent or good reasons.

4. Parents, teachers, and students would rise to the defense of this school's program if it were challenged.

5. I like working in this school.

OPPORTUNITY FOR INPUT:

1. I feel that my ideas are listened to and used in this school.

2. When important decisions are made about programs in this school, I, personally, have heard about the plan beforehand and have been involved in some of the discussions.

3. Important decisions are made in this school by a governing council with representation from students, faculty, and administration.

4. While I obviously can't have a vote on every decision that is made in this school that affects me, I do feel that I can have some important input into that decision.

5. When all is said and done, I feel that I count in this school.

$\begin{array}{llll}1 & 2 & 3 & 4 \\ 1 & 2 & 3 & 4 \\ 1 & 2 & 3 & 4 \\ 1 & 2 & 3 & 4 \\ 1 & 2 & 3 & 4\end{array}$

CONTINUOUS ACADEMIC AND SOCIAL GROWTH:

1. Teaches are "alive"; they are interested in life around them; they are doing interesting things outside the school.

2. Teachers in this school are "out in front", seeking better ways of teaching and learning.

3. Students feel that the school program is meaningful and relevant to their present and future needs.

4. The principal is growing and learning too. He or she is seeking new ideas.

5. The school supports parent growth. Regular opportunities are provided for parents to be involved in learning activities and in examining new ideas.

$\begin{array}{llll}1 & 2 & 3 & 4 \\ 1 & 2 & 3 & 4 \\ 1 & 2 & 3 & 4 \\ 1 & 2 & 3 & 4 \\ 1 & 2 & 3 & 4\end{array}$

\section{COHESIVENESS:}

1. Students would rather attend this school than transfer to another.

2. There is a" we" spirit in this school.

3. Administration and teachers collaborate toward making the school run effectively; there is little administrator - teacher tension.

4. Differences between individuals and groups (both faculty and students) are considered to contribute to the richness of the school, not as divisive influences.

5. New students and faculty members are made to feel welcome and part of the group.

\section{SCHOOL RENEWAL:}

1. When a problem comes up, this school has procedures for working on it; problems are seen as normal challenges, not as "rocking the boat."

2. Teachers are encouraged to innovate in their classrooms rather than conform.

3. When a student comes along who has special problems, this school works out a plan that helps the student.

4. Students are encouraged to be creative rather than to conform.

5. Careful effort is made, when new programs are introduced, to adapt them to the particular needs of this community and this school.

CARING:

1. There is someone in this school I can always count on.

2. The principal really cares about students.

3. I think people in this school care about me as a person and are concerned about more than just how well I perform my role at school.

4. I feel wanted and needed in this school.

5. Most people at this school are kind.

$\begin{array}{llll}1 & 2 & 3 & 4 \\ 1 & 2 & 3 & 4 \\ 1 & 2 & 3 & 4 \\ 1 & 2 & 3 & 4 \\ 1 & 2 & 3 & 4\end{array}$




\section{Vita for Elaine DellaMea Gayton}

EMPLOYMENT: 1995 - current

POSITION:

$1982-1995$

POSITION:

Ed. D.

Major:

Minor:

M. S.

Major:

B. A.

Major:
Kanawha County Schools

200 Elizabeth Street

Charleston, West Virginia 25311

Elementary Curriculum Specialist

Kanawha County Schools

200 Elizabeth Street

Charleston, West Virginia 25311

Elementary Teacher

West Virginia University

Education Leadership

Morgantown, West Virginia

Education Administration

Curriculum \& Instruction

West Virginia University

Morgantown, West Virginia

Counseling

Fairmont State College

Fairmont, West Virginia

Elementary Education
PROFESSIONAL

MEMBERSHIPS:

\author{
Association for Supervision and Curriculum Development \\ International Reading Association \\ West Virginia Reading Association \\ Kanawha County Reading Association
}

